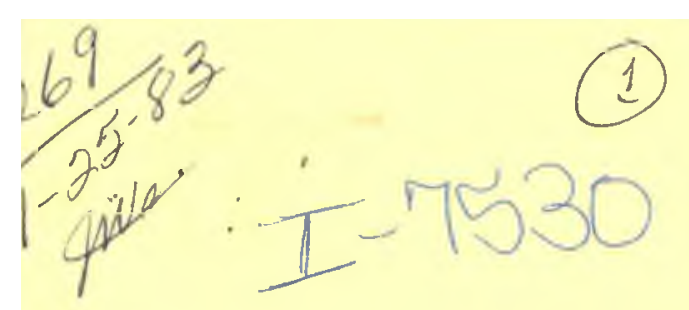

\title{
Selected Measurement Data for Plutonium and Uranium
}

M. Edward Anderson and John F. Lemming

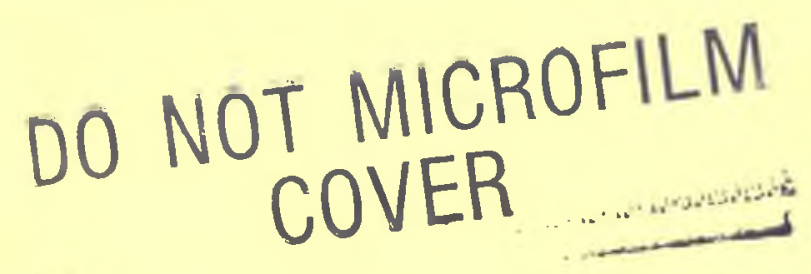

\section{IAEA}

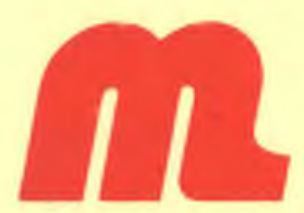




\section{DISCLAIMER}

This report was prepared as an account of work sponsored by an agency of the United States Government. Neither the United States Government nor any agency Thereof, nor any of their employees, makes any warranty, express or implied, or assumes any legal liability or responsibility for the accuracy, completeness, or usefulness of any information, apparatus, product, or process disclosed, or represents that its use would not infringe privately owned rights. Reference herein to any specific commercial product, process, or service by trade name, trademark, manufacturer, or otherwise does not necessarily constitute or imply its endorsement, recommendation, or favoring by the United States Government or any agency thereof. The views and opinions of authors expressed herein do not necessarily state or reflect those of the United States Government or any agency thereof. 


\section{DISCLAIMER}

Portions of this document may be illegible in electronic image products. Images are produced from the best available original document. 
NOTICE

PORTIONS OF THIS REPORT ARE ILLEGIBLE, It has been reproduced from the best available copy to permit the broadest possible avaik

\section{Selected Measurement MLM--3009 Data for Plutonium DE83 007038 and Uranium}

M. Edward Anderson and John F. Lemming

November 1982

This report was prepared as an account of work spansored by an agency of the United States Government Neither the Lnited States Government nor any dqency thered nor eny of the gmplcyess makes any warranty. express or implied, or assumes any legal liability or responsibility for the mates any completeness. or usetulness af any information, apperatus, product or process disclosed, or represents that its use would not infringe privately owned rights. Reference herein to any specitic

commercial product, process, or service by trąde name, trademark, manufacturer, or otherwise dces not necessarily constitute ar imply its endorsement, recommendation, or fovering by the Unice States Government or any agency thereot The vieus and on nions of a whors exorcued heren ao noe necessarily state or reflect thoss of the United States Government or any agency thereot

\section{MOUND}

MIAMISBURG, OHIO 45342

operated by

\section{$\checkmark$ MONSANTO RESEARCH CORPORATION}

a subsidiary of Monsanto Company

for the

U.S. DEPARTMENT OF ENERGY

Contract No. DE-AC04-76-DP00053 


\section{Contents}

PREFACE

1. INTRODUCTION $\ldots \ldots \ldots \ldots \ldots \ldots \ldots \ldots \ldots \ldots \ldots$

2. PROPERTY TYPES AND THEIR LIMITATIONS $\ldots \ldots .2$

3. CONFIDENCE RANKINGS OF PROPERTIES ....... 6

3.1 Plutonium .......................... 8

3.1.1 Pu Metal ....................... 8

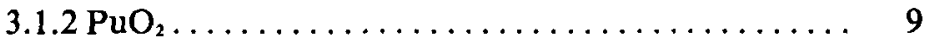

3.1.3 Pu Nitrate $\ldots \ldots \ldots \ldots \ldots \ldots \ldots \ldots \ldots \ldots \ldots \ldots$

3.1.4 Pu Scrap........................ 11

3.1.5 Neutron Sources ................. 12

3.2 High Enriched Uranium $\ldots \ldots \ldots \ldots \ldots \ldots \ldots \ldots . \ldots \ldots$

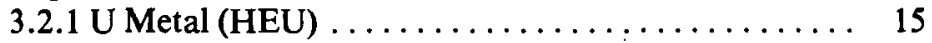

3.2.2 $\mathrm{UO}_{2}, \mathrm{U}_{3} \mathrm{O}_{8}(\mathrm{HEU}) \ldots \ldots \ldots \ldots \ldots \ldots \ldots \ldots \ldots, 16$

3.2.3 Uranium Nitrate (HEU) $\ldots \ldots \ldots \ldots \ldots \ldots \ldots \ldots$

3.2.4 $\mathrm{UF}_{6}, \mathrm{UF}_{4}(\mathrm{HEU}) \ldots \ldots \ldots \ldots \ldots \ldots \ldots \ldots \ldots, 19$

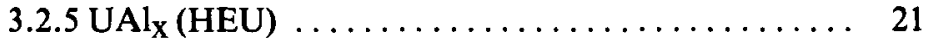

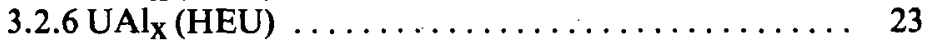

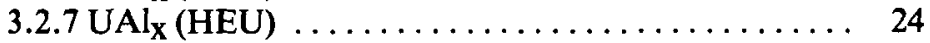

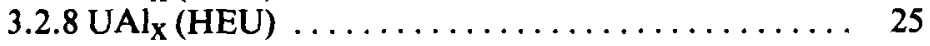

3.3 Plutonium/Uranium $\ldots \ldots \ldots \ldots \ldots \ldots \ldots \ldots \ldots, 26$

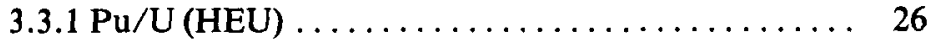

3.3.2 $\mathrm{PuO}_{2} / \mathrm{UO}_{2} \ldots \ldots \ldots \ldots \ldots \ldots \ldots \ldots \ldots \ldots \ldots . \ldots \ldots$

3.3.3 $\mathrm{PuO}_{2} / \mathrm{UO}_{2}(\mathrm{HEU}) \ldots \ldots \ldots \ldots \ldots \ldots \ldots \ldots \ldots, 28$

4. NUCLEAR DATA FOR

VERIFICATION MEASUREMENTS ........... 29

4.1 Plutonium .............................. 29

4.1.1 Neutron Properties .................. 30

4.1.2 Gamma-ray Properties ............... 45

4.1.3 Thermal Properties ................ 58

4.2 Uranium $\ldots \ldots \ldots \ldots \ldots \ldots \ldots \ldots \ldots \ldots \ldots \ldots .61$

4.2.1 Neutron Properties .................. 62

4.2.2 Gamma-ray Properties............... 67

4.2.3 Thermal Properties................. 73

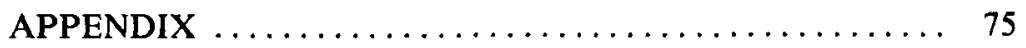

REFERENCES $\ldots \ldots \ldots \ldots \ldots \ldots \ldots \ldots \ldots \ldots \ldots \ldots \ldots \ldots \ldots \ldots$ 


\section{Preface}

This handbook was supported by the Program for Technical Assistance to IAEA Safeguards. It is designed primarily for use by inspectors when verifying the nuclear material contents of samples by nondestructive means. It contains discussions of various properties and the applicability of the measurement of these properties toward verification of specific samples. Because the thrust of this handbook is with properties rather than techniques or instruments, portions of it may be useful to other analysts as a reference. 


\section{Introduction}

The nuclear material content of a sample can generally be established by measuring one or more properties of the sample with nondestructive assay (NDA) techniques. The degree of confidence in the result will depend not only on the precision of the measurement, but also on certain assumptions made about the sample. These assumptions (probably supplied by the holder of the inventory) could concern the chemical and isotopic composition of the fissionable material in the sample, the composition of the sample matrix, and the configuration of the nuclear material in the container. In cases where assumptions have been made, the result of an NDA measurement should be considered an estimate of the amount of nuclear material actually in the sample. For instance, in a plutonium sample, the thermal power together with an assumed isotopic composition will yield a value for the nuclear material content but will not ensure that the nuclear material is present. Similarly, a high-resolution gamma-ray spectrum can establish the presence of a nuclear material, but without additional information, it says little about the quantity of nuclear material in the sample. Combining both properties, the thermal power and a gamma-ray spectrum, increases confidence that the nuclear material is present at a stated amount. Still, this alone may not produce the degree of confidence desired, and additional information from other measurements or calculations may be required.

Some properties that can be used to verify the nuclear material content of a sample are discussed in this Handbook. Section 2 summarizes these properties, the information that can be gained from their measurements, and the limitations associated with this information. Section 3 presents property rankings for different sample types in terms of increasing confidence for sample verification. Section 4 is a summary of nuclear data related to sample verification.

Discussions of mass, volume, and density are not included in this Handbook. Gamma-ray attenuation in container walls is discussed (page 51), although measuring the wall thickness (e.g., by ultrasonics) is not discussed. However, information about all these properties can be, and in some cases should be, combined with properties discussed in this Handbook to bring added confidence to sample verification. 


\section{Property Types and Their Limitations}

Various sample properties and the information that can be gained from measuring each property are summarized in Table 1 . The table is so arranged that, as more is known about the sample (from top to bottom under any single property), the information gained about the sample becomes more specific.

In Table 1, "valid calibration" indicates that all parameters that might affect a calibration are known. These could include: chemical compositions of the nuclear material and matrix, the isotopic composition of the nuclear material, sample geometry including container attenuation, and sample homogeneity. "Assumed calibration" signifies that one or more of the parameters is not known. Until it has been established that a calibration is valid for a given sample, results must be looked on as approximations. A large part of building confidence in sample verification is gaining assurance that a given calibration and a given sample are well matched.

Each of the properties listed in Table 1 has limitations that can reduce confidence in measurements. Some of these limitations are discussed below:

Neutron counting rates - a) Neutron emission could be from unexpected sources including $(\alpha, n)$ reactions with impurities and from spontaneously fissioning nuclides such as ${ }^{244} \mathrm{Cm}$ and ${ }^{252} \mathrm{Cf}$. b) The sample geometry may not be the same as that used when calibrating the measurement system, thereby possibly invalidating the calibration. c) A sample might contain neutron moderating materials, such as hydrogen, which could adversely affect an assay. One of the effects of neutron moderation can be an increase in the rate of plutonium or uranium fissioning. This can lead to increased neutron multiplication and an overstatement of the assay value. Another effect of moderation is that, in an active assay system using unmoderated neutrons for interrogation, moderation of these neutrons by the sample can increase the system's response - again resulting in erroneously high assay values. Detection of moderated neutrons might also be more efficient than detection of unmoderated neutrons, thus invalidating a calibration curve based on no moderation.

A verage neutron energy - If the measure of average neutron energy is determined from the ratio of two counting rates, there can be no assurance that two or more different spectra have not been combined in order to yield the same result a single spectrum would yield. 
Gamma-ray spectrum - a) The attenuation coefficients for gamma rays of interest are large enough that for many samples only those gamma rays originating near the sample surface leave the sample. Therefore, except for liquid samples that have been shaken and for small samples, there can be no assurance an isotopic ratio determination obtained from a gamma spectrum is valid for an entire sample. b) A given spectral peak may be composed of unresolved energies leading to erroneous assay results. This is especially significant for a low resolution measurement such as a $\mathrm{NaI}$ spectrum but also can be a factor in a high resolution Ge spectrum.

Gamma-ray transmission ratio - Gamma rays may be attenuated by materials other than the material for which the assay is being performed.

Thermal power - Sources of heat could be present, including chemical reactions, which are not related to the quantity of nuclear material being assayed. 
TABLE 1 - INFORMATION TO BE GAINED BY MEASURING VARIOUS SAMPLE PROPERTIES

\begin{tabular}{|c|c|c|}
\hline Property & $\begin{array}{c}\text { Additional Information } \\
\text { Needed }\end{array}$ & Information Gained \\
\hline \multirow{4}{*}{$\begin{array}{l}\text { Total neutron } \\
\text { counting rate } \\
\text { (passive measurement) }\end{array}$} & None & $\begin{array}{l}\text { Whether neutrons from fission and/or }(\alpha, n) \text { reactions } \\
\text { are present }\end{array}$ \\
\hline & Detector efficiency & $\begin{array}{l}\text { Total neutron emission rate from fission and }(a, n) \\
\text { reactions }\end{array}$ \\
\hline & Assumed calibration & Limits on quantity of nuclear material \\
\hline & Valid calibration & Quantity of nuclear material. \\
\hline \multirow{4}{*}{$\begin{array}{l}\text { Coincident neutron } \\
\text { counting rate } \\
\text { (passive measurement) }\end{array}$} & None & Whether neutrons from fission are present \\
\hline & Detector efficiency & Coincident neutron emission rate \\
\hline & Assumed calibration & l.imits on quantity of nuclear material \\
\hline & Valid calibration & Quantity of nuclear material \\
\hline $\begin{array}{l}\text { Average neutron energy } \\
\text { (ratio measurement) }\end{array}$ & None & Whether the average neutron energy $i$ \\
\hline
\end{tabular}




\section{High-resolution}

gamma-ray spectrum
Energy calibration

Ratios of peak areas for a given isotope and relative detection efficiencs

Ratios of peak areas

for different isotopes of a given element and relative detection efficiency

Absolute detector efficiency

Assumed calibration

Valid calibration

Low-resolution gamma- Same as above for high-

ray spectrum

resolution gamma-ray

ipecirum

Gamma-ray transmission None

ratio

Assumed calibration

Valid calibration

Total thermal power Sample mass

Isolopic composition of nuclear material
Identification of radionuclider

Assurance that gamma ravs are from a specitio radionuclide

lsolope composition

Gamma-ray emission rates

L imits on quantity of nuclear material

Quantity of nuclear material

Same as above for high-rescilution gamma-ray spectrum, except there is les assurance a given peak is free from interferences

Cianma-ray attenuation

Limits on quantity of nuclear material

Quantity of nuclear material

Thermal power per unit mass of sample

Quantity of nuclear material 


\section{Confidence Rankings of Properties}

Properties are ranked for each sample type in order of increasing confidence for establishing sample authenticity. These rankings are subjective and may be different in specific situations if certain a priori information of high confidence is available. In some cases, the ease of measuring a particular property enters into the ranking.

Generally, a neutron emission rate is ranked lower than a gamma-ray spectrum. This is because the neutron measurement is nonspecific, whereas the gamma-ray measurement does establish the presence of the isotope of interest (even if its presence can be established only to a limited depth in the sample due to self-attenuation). One advantage of a neutron measurement is that sample attenuation is usually small or negligible, hence the detector generally "sees" most of the sample. A thermal power measurement (e.g., of a plutonium sample) is also nonspecific. By itself, it would usually have the same ranking as a coincident neutron measurement. However, because a thermal power measurement is a time consuming process, it would generally not be done singly unless one had a high degree of confidence in the stated isotopic composition of the sample. If that were the case, such a measurement would have a high confidence ranking.

Many of the individual data sheets contain values for $1 \%$ and $50 \%$ transmission of certain energy gamma rays. These have been included to help the user estimate whether a sample can be considered "infinitely thick" for an enrichment measurement or whether a transmission measurement might be done. A sample whose transmission is $\leqslant 1 \%$ can often be considered infinitely thick (see page 56). The thickness for $50 \%$ transmission is sometimes called a half-value layer (see page 51).

More properties are listed on some data sheets than may generally be measured in sample verification. However, confidence will be higher as more properties are used to assess the nuclear material content of a sample.

The discussions for each sample type are necessarily brief and are intended to be supplemented by the information in Section 4 . 
On the individual data sheets X's are used to indicate that a property is measured. The position of an $\mathrm{X}$ indicates the relative confidence ranking: higher rankings are further to the right. For example, on the data sheet for $\mathrm{Pu}$ metal (page 8) a coincident neutron counting rate (passive) has a higher confidence ranking than a total neutron counting rate (passive). In general, if two or more properties are measured, the confidence for the combinations will be greater than for a single measurement.

Symbols used on the data sheets are:
Q - density
HRGS - high resolution gamma-ray spectrometry
LRGS - low resolution gamma-ray spectrometry
HEU - high enriched uranium
$\mathrm{x}(50 \%)$ - thickness for $50 \%$ transmission
$\mathrm{x}(1 \%)$ - thickness for $1 \%$ transmission 


\subsection{Plutonium}

\subsubsection{Pu Metal}

Description: Metal pieces in sealed cans, $1-200 \mathrm{~g} \mathrm{Pu} / \mathrm{batch}$;

\section{Ranking:} Q: $19.6 \mathrm{~g} / \mathrm{cm}^{3}$.

\begin{tabular}{|c|c|c|c|c|c|c|}
\hline Property & \multicolumn{6}{|c|}{ Increasing Confidence $\rightarrow$} \\
\hline & \multicolumn{2}{|c|}{ Single } & \multicolumn{4}{|c|}{ Combination } \\
\hline $\begin{array}{l}\text { Total neutron counting } \\
\text { rate (passive) }\end{array}$ & $\mathrm{X}$ & & & & & \\
\hline $\begin{array}{l}\text { Coincident neutron } \\
\text { counting rate (passive) }\end{array}$ & $\mathrm{X}$ & & $\mathrm{X}$ & & $\mathrm{X}$ & \\
\hline $\begin{array}{l}\text { Gamma-ray spectrum } \\
\text { (HRGS) }\end{array}$ & & $\mathrm{X}$ & $\mathrm{X}$ & $\mathrm{X}$ & $\mathbf{X}$ & $\mathrm{X}$ \\
\hline Thermal power & & & & $\mathrm{X}$ & $\mathrm{X}$ & $\mathrm{X}$ \\
\hline $\begin{array}{l}\text { Coincident neutron } \\
\text { counting rate (active) }\end{array}$ & & & & & & $\mathrm{X}$ \\
\hline
\end{tabular}

\section{Discussion:}

Neutron - $\quad$ The primary neutron source is spontaneous fission. Neutron yields depend on the plutonium isotopic composition, (see Table 4 on page 31 ). Neutron multiplication is $<1.3$ for a $200 \mathrm{~g}$ sample. Neutrons emitted in an active measurement using subthreshold neutron interrogation are due primarily to induced fission of ${ }^{239} \mathrm{Pu}$ and ${ }^{241} \mathrm{Pu}$.

Gamma ray - $\quad$ The thicknesses of Pu metal $\left(\varrho=19.6 \mathrm{~g} / \mathrm{cm}^{3}\right)$ for $50 \%$ and $1 \%$ transmissions are:

\begin{tabular}{|c|c|c|}
\hline $\begin{array}{c}\mathrm{E}_{\gamma} \\
(\mathrm{keV})\end{array}$ & $\begin{array}{c}\times(50 \%) \\
(\mathrm{cm})\end{array}$ & $\begin{array}{c}x(1 \%) \\
(\mathrm{cm})\end{array}$ \\
\hline 129 & 0.01 & 0.06 \\
\hline 375 & 0.11 & 0.73 \\
\hline 414 & 0.13 & 0.87 \\
\hline
\end{tabular}

Thermal power - Thermal power is independent of the physical and chemical form of the plutonium. It does depend on the plutonium isotopic composition. 


\subsection{2 $\mathrm{PuO}_{2}$}

Description: Powder in sealed cans, $0.05-2 \mathrm{~kg} \mathrm{Pu} / \mathrm{batch}$; theoretical $\varrho: 11.46 \mathrm{~g} / \mathrm{cm}^{3}$.

\section{Ranking:}
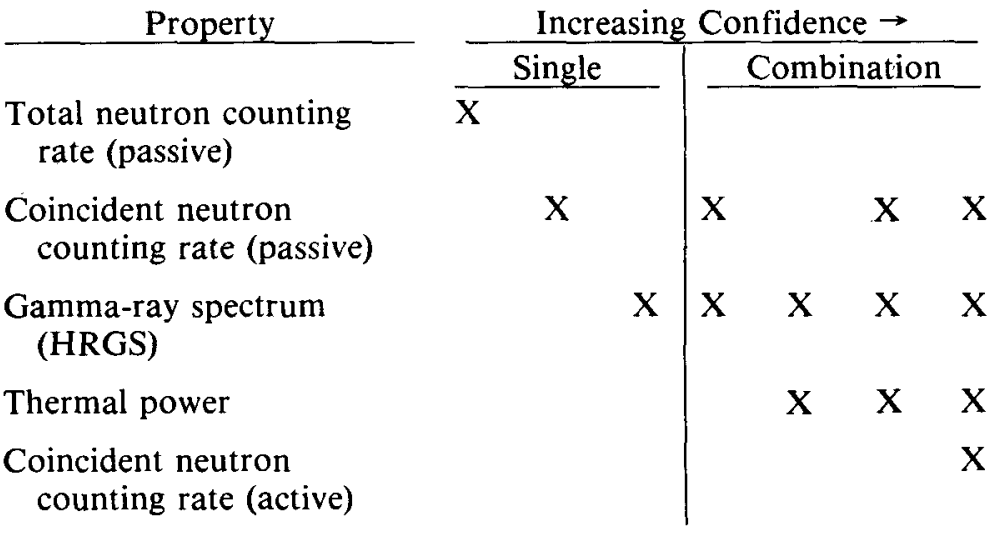

Total neutron counting rate (passive)

Coincident neutron counting rate (passive)

Gamma-ray spectrum (HRGS)

Thermal power

Coincident neutron counting rate (active)

\section{Discussion:}

Neutron -

Neutron yields depend on plutonium isotopic composition. Neutrons from $\mathrm{O}(\alpha, \mathrm{n})$ reactions will contribute between $30 \%$ and $45 \%$ of the total neutron emission rate (see Table 4). Neutron multiplication is less than that for an equivalent weight of $\mathrm{Pu}$ metal. Multiplication for a $2-\mathrm{kg} \mathrm{Pu}$ sample will be $<1.4$. The neutrons emitted in an active measurement using subthreshold neutrons are due primarily to fissioning of ${ }^{239} \mathrm{Pu}$ and ${ }^{241} \mathrm{Pu}$.

Gamma ray - Gamma rays from the $O(\alpha, n)$ reaction are too weak to be seen in a spectrum. The thicknesses of $\mathrm{PuO}_{2}$ for $50 \%$ and $1 \%$ transmissions of the 414 $\mathrm{keV}$ gamma ray for different densities are given below:

$\begin{array}{ccc}\begin{array}{c}\varrho \\ \left(\mathrm{g} / \mathrm{cm}^{3}\right)\end{array} & \begin{array}{c}\mathrm{x}(50 \%) \\ (\mathrm{cm})\end{array} & \begin{array}{c}\mathrm{x}(1 \%) \\ (\mathrm{cm})\end{array} \\ 3.0 & 0.93 & 6.2 \\ 5.0 & 0.56 & 3.7 \\ 11.5 & 0.24 & 1.6\end{array}$

Thermal power - Thermal power is independent of the physical and chemical form of the plutonium, but does depend on the plutonium isotopic composition. 


\subsubsection{Pu Nitrate}

Description: Solution in 9-liter bottle, $\sim 2-\mathrm{kg} \mathrm{Pu} /$ batch; Q: $\sim 222 \mathrm{~g} \mathrm{Pu} /$ liter

\section{Ranking:}

\begin{tabular}{lccc}
\multicolumn{1}{c}{ Property } & \multicolumn{2}{c}{ Increasing Confidence $\rightarrow$} \\
$\begin{array}{l}\text { Gamma-ray spectrum } \\
\text { (HRGS) }\end{array}$ & $\mathrm{X}$ & Combination \\
$\begin{array}{l}\text { Gamma-ray transmission } \\
\text { ratio }\end{array}$ & $\mathrm{X}$ & $\mathrm{X}$ \\
& & $\mathrm{X}$
\end{tabular}

\section{Discussion:}

Appearance - The color depends on both the acid concentration and the plutonium valence state. In dilute acid the colors are: Pu III-blue, Pu IV-yellowish brown, $\mathrm{Pu}$ V-pink, and Pu VI-green. In concentrated acid the most stable state is $\mathrm{Pu} \mathrm{IV}$, and its color is green.

Neutron - The neutron emission rate is from $O(\alpha, n)$ and spontaneous fission reactions. The $\mathrm{O}(\alpha, \mathrm{n})$ yields in Table 4 must be multiplied by $\sim 1.8$ for plutonium nitrate solution. Multiplication corrections are not generally available.

Gamma ray - Gamma rays from the same isotope (e.g., 129 and $414 \mathrm{keV}$ for ${ }^{239} \mathrm{Pu}$ ) can be used to determine plutonium concentration (see page 53). Solution thicknesses for $50 \%$ and $1 \%$ transmission are:

\begin{tabular}{|c|c|c|c|}
\hline $\begin{array}{c}\mathrm{E}_{\gamma} \\
(\mathrm{keV})\end{array}$ & $\begin{array}{c}\mu Q \\
\left(\mathrm{~cm}^{-1}\right)\end{array}$ & $\begin{array}{c}\mathrm{x}(50 \%) \\
(\mathrm{cm})\end{array}$ & $\begin{array}{c}x(1 \%) \\
(\mathrm{cm})\end{array}$ \\
\hline 129 & 1.0 & 0.7 & 4.6 \\
\hline 414 & 0.17 & 4.1 & 27 . \\
\hline
\end{tabular}

Thermal power - Thermal power measurements are unreliable for solution samples because of chemical reactions that are often present. 


\subsubsection{Pu Scrap}

Description: $\mathrm{Pu}$ and $\mathrm{PuO}_{2}$ in a variety of matrices and contained in cans, jars, etc., $10-1000 \mathrm{~g} /$ batch.

\section{Ranking:}

In general, the ranking is the same as for the feed material.

\section{Discussion:}

Matrix interferences are extremely important. Calibration standards may be hard to obtain because of sampling problems and the imprecise definition of the waste/scrap category. Calorimetric assay may be useful in preparing calibration standards. 


\subsubsection{Neutron Sources}

Description: $\mathrm{Pu}-\mathrm{Be}, \mathrm{Pu}-\mathrm{F}, \mathrm{Pu}-\mathrm{O}$, and $\mathrm{Pu}-\mathrm{Li}$ in welded containers; $3-80 \mathrm{~g} /$ source.

\section{Ranking:}

\begin{tabular}{|c|c|c|c|c|}
\hline Property & \multicolumn{4}{|c|}{ Increasing Confidence $\rightarrow$} \\
\hline & Single & & bin & \\
\hline $\begin{array}{l}\text { Total neutron } \\
\text { counting rate (passive) }\end{array}$ & $\mathrm{X}$ & $\mathrm{X}$ & $\mathrm{X}$ & $\mathrm{X}$ \\
\hline $\begin{array}{l}\text { Average neutron } \\
\text { energy }\end{array}$ & & $\mathrm{X}$ & & $\mathbf{X}$ \\
\hline $\begin{array}{l}\text { Gamma-ray spectrum } \\
\text { (HRGS) }\end{array}$ & $\mathrm{X}$ & & $\mathrm{X}$ & $\mathrm{X}$ \\
\hline Thermal power & & & & $\mathrm{X}$ \\
\hline
\end{tabular}

\section{Discussion:}

For all plutonium $(\alpha, n)$ neutron sources, the neutron yield will depend on the plutonium and americium isotopic composition, the age of the source, the alpha-emitter to target atom ratio, and how homogeneously the alpha-emitter and target are mixed on a microscopic scale. For target elements with more than one naturally occurring isotope, the neutron yield will also depend on the target isotopic composition.

The coincident counting rate will be due to neutrons from spontaneous fission and from self-multiplication (which is dependent on the total neutron yield).

Average neutron energy will depend primarily on the $(\alpha, n)$ reactions present and secondarily on fission reactions and source size.

The gamma-ray energy spectrum will be a function of the plutonium and americium isotopic composition, $\alpha$-particle induced reactions, and the source size, shape, and containment.

\section{$\mathrm{Pu}-\mathrm{Be}$}

Beryllium $(\alpha, \mathrm{n})$ thick target neutron yields for different isotopes are given in Table 4. However, in $\mathrm{Pu}-\mathrm{Be}$ sources the $\mathrm{Be} / \mathrm{Pu}$ atom ratio is usually $>1$. A common ratio is $\mathrm{Be} / \mathrm{Pu}=13$, and for this the neutron yield is $66 \%$ of the thick target yield. 
The average neutron energy for a ${ }^{239} \mathrm{Pu}$-Be source varies from $\sim 4.5$ $\mathrm{MeV}$ for a source containing $1 \mathrm{~g}$ of plutonium to $\sim 3.9 \mathrm{MeV}$ for one containing $160 \mathrm{~g}$.

The gamma-ray energy spectrum will contain a Doppler-broadened $4439 \mathrm{keV}$ line from the ${ }^{9} \mathrm{Be}(\alpha, \mathrm{n})^{12} \mathrm{C}$ reaction.

\section{$\underline{\mathrm{Pu}-\mathrm{F}}$}

The source composition will probably be $\mathrm{PuF}_{4}$ and neutron yields for this compound for different plutonium isotopes are given in Table 4.

Average neutron energy is $\sim 1.4 \mathrm{MeV}$.

A gamma ray energy spectrum will contain several lines from $(\alpha, n)$, $(\alpha, p)$, and $\left(\alpha, \alpha^{\prime}\right)$ reactions with ${ }^{19} \mathrm{~F}$. Among these are those at 511, $583,891,1274$, and $2083 \mathrm{keV}$ with the $2083 \mathrm{keV}$ line Doppler broadened. Some of the 511 and $1274 \mathrm{keV}$ gamma rays will come from ${ }^{22} \mathrm{Na}$ produced in the source. Since the half-life of ${ }^{22} \mathrm{Na}$ is 2.6 $\mathrm{yr}$, the intensity of these two lines will depend on the age of the source.

\section{$\underline{\mathrm{Pu}-\mathrm{O}}$}

The source composition will likely be $\mathrm{PuO}_{2}$. Naturally occurring oxygen is $99.758 \%{ }^{16} \mathrm{O}, 0.038 \%{ }^{17} \mathrm{O}$, and $0.204 \%{ }^{18} \mathrm{O}$. Of these only ${ }^{17} \mathrm{O}$ and ${ }^{18} \mathrm{O}$ can undergo oxygen $(\alpha, n)$ reactions with plutonium $\alpha$-particles. Because of the low neutron yield for a source with natural oxygen, the oxygen in a ${ }^{239} \mathrm{Pu}-\mathrm{O}$ source will likely be enriched in ${ }^{18} \mathrm{O}$. The neutron yield from ${ }^{18} \mathrm{O}(\alpha, \mathrm{n})$ reactions in $\mathrm{PuO}_{2}$ will be 450 times greater than those shown in Table 4 for natural oxygen. For ${ }^{17} \mathrm{O}$ the neutron yield is 210 times greater. Since ${ }^{237} \mathrm{Pu}$ has a relatively low specific activity, the principal $\alpha$-emitter in a $\mathrm{Pu}-\mathrm{O}$ soirce might be ${ }^{238} \mathrm{Pu}$.

The average neutron energy for a $\mathrm{Pu}-\mathrm{O}$ source is $\sim 2 \mathrm{MeV}$.

The gamma-ray energy spectrum will contain lines from the ${ }^{18} \mathrm{O}(\alpha, \mathrm{n})^{2} \mathrm{Ne}$ reaction at 350,1395 , and $2438 \mathrm{keV}$. The $1395 \mathrm{keV}$ line is Doppler broadened. If the ${ }^{17} \mathrm{O}(\alpha, \mathrm{n})^{20} \mathrm{Ne}$ reaction is present, there will also be a line at $1634 \mathrm{keV}$. 


\section{$\mathrm{Pu}-\mathrm{Li}$}

This source type is likely to be a mixture of $\mathrm{PuO}_{2}$ and $\mathrm{Li}_{2} \mathrm{O}$ with the $\mathrm{Li}_{2} \mathrm{O} / \mathrm{PuO}_{2}$ molecular ratio $>1$. Natural lithium is $7.5 \%{ }^{6} \mathrm{Li}$ and 92.5\% ${ }^{7} \mathrm{Li}$ - only ${ }^{7} \mathrm{Li}$ will undergo the $\mathrm{Li}(\alpha, \mathrm{n})$ reaction with plutonium $\alpha$-particles. Since the ${ }^{239} \mathrm{Pu}$ specific activity is relatively low, the principal $\alpha$-emitter in a $\mathrm{Pu}$ - $\mathrm{Li}$ source is probably ${ }^{238} \mathrm{Pu}$. The $(\alpha, n)$ yields are given below for a thick $\mathrm{Li}_{2} \mathrm{O}$ target with lithium of natural abundance. The total neutron yield is the sum of the $(\alpha, n)$ and spontaneous fission yields given in Table 4.

$\begin{array}{cc}\text { Isotope } & \begin{array}{c}\text { Li }(\alpha, \mathrm{n}) \text { Yields } \\ \text { (n/sec-g of isotope) }\end{array} \\ { }^{238} \mathrm{Pu} & 6.8 \times 10^{5} \\ { }^{239} \mathrm{Pu} & 1.1 \times 10^{3} \\ { }^{240} \mathrm{Pu} & 4.2 \times 10^{3} \\ { }^{241} \mathrm{Pu} & 2.0 \times 10^{1} \\ { }^{2+2} \mathrm{Pu} & 3.1 \times 10^{1} \\ { }^{241} \mathrm{Am} & 1.4 \times 10^{5}\end{array}$

The average neutron energy is $\sim 0.5 \mathrm{MeV}$.

The gamma-ray energy spectrum will include a Doppler-broadened line at $478 \mathrm{keV}$ from the ${ }^{\prime} \mathrm{Li}\left(\alpha, \alpha^{\prime}\right)$ reaction. 


\subsection{High Enriched Uranium}

\subsubsection{U Metal (HEU)}

Description: U metal sealed in cans, $30-5000 \mathrm{~g}{ }^{235} \mathrm{U} / \mathrm{batch}$; Q: $19.05 \mathrm{~g} / \mathrm{cm}^{3}$.

\section{Ranking:}

\begin{tabular}{lcr|c}
\multicolumn{1}{c}{ Property } & \multicolumn{2}{c}{ Increasing Confidence $\rightarrow$} \\
\cline { 2 - 3 } $\begin{array}{l}\text { Gamma-ray spectrum } \\
\text { (LRGS) }\end{array}$ & $\mathrm{X}$ & & Combination \\
$\begin{array}{l}\text { Gamma-ray spectrum } \\
\text { (HRGS) }\end{array}$ & $\mathrm{X}$ & $\mathrm{X}$ \\
$\begin{array}{l}\text { Coincident neutron } \\
\text { counting rate (active) }\end{array}$ & & $\mathrm{X}$ & $\mathrm{X}$
\end{tabular}

\section{Discussion:}

Neutron - $\quad$ The primary source of neutrons in a passive measurement is spontaneous fission of evennumbered isotopes (see Table 17 on page 63 ). The neutron emission rate will depend on the uranium isotopic abundance but will generally be low. Neutron multiplication will be $<1.8$ for a $2.5 \mathrm{~kg}$ $\left({ }^{235} \mathrm{U}\right)$ sample.

Gamma ray - Thickness of $U$ metal for $50 \%$ and $1 \%$ transmissions of the $186 \mathrm{keV}$ gamma ray is $0.025 \mathrm{~cm}$ and $0.17 \mathrm{~cm}$ respectively. For recycled uranium, interferences may require the use of HRGS. Wall thickness and composition are required for enrichment measurements. 


\subsection{2 $\mathrm{UO}_{2}, \mathrm{U}_{3} \mathrm{O}_{8}(\mathrm{HEU})$}

Description: Powder in stainless steel or aluminum cans, $<5 \mathrm{~kg}{ }^{235} \mathrm{U} / \mathrm{batch}$; pressed powder in stainless steel sheathed rods, $\sim 200 \mathrm{~g}{ }^{233} \mathrm{U} /$ batch; Q: $\mathrm{UO}_{2}-10.96 \mathrm{~g} / \mathrm{cm}^{3} ; \mathrm{U}_{3} \mathrm{O}_{8}-8.30 \mathrm{~g} / \mathrm{cm}^{3}$

Ranking:

\begin{tabular}{llll}
\multicolumn{1}{c}{ Property } & & \multicolumn{2}{c}{ Increasing Confidence $\rightarrow$} \\
$\begin{array}{l}\text { Gamma-ray spectrum } \\
\text { (LRGS) }\end{array}$ & $\mathrm{X}$ & & Combination \\
$\begin{array}{l}\text { Gamma-ray spectrum } \\
\text { (HRGS) }\end{array}$ & $\mathrm{X}$ & \\
$\begin{array}{l}\text { Coincident neutron } \\
\text { counting rate (active) }\end{array}$ & & $\mathrm{X}$ & $\mathrm{X}$ \\
\end{tabular}

\section{Discussion:}

Neutron - $\quad$ Neutron yield from active interrogation with subthreshold neutrons is due primarily to ${ }^{235} \mathrm{U}$. For counting rods, geometry corrections are especially important. Calculated passive neutron yields for nonmultiplying $\mathrm{UO}_{2}$ from oxygen $(\alpha, \mathrm{n})$ and spontaneous fission reactions are approximately :

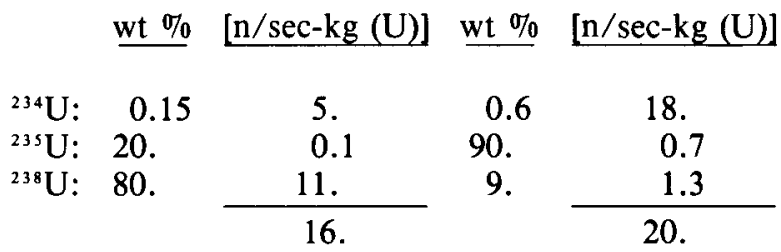

Gamma ray - Thicknesses of uranium oxide for $50 \%$ and $1 \%$ transmission of $186 \mathrm{keV}$ gamma ray:

\begin{tabular}{|c|c|c|}
\hline $\begin{array}{c}\varrho \\
\left(\mathrm{g} / \mathrm{cm}^{3}\right) \\
\end{array}$ & $\begin{array}{c}x(50 \%) \\
(\mathrm{cm}) \\
\end{array}$ & $\begin{array}{c}x(1 \%) \\
(\mathrm{cm})\end{array}$ \\
\hline 3.0 & 0.18 & 1.2 \\
\hline 5.0 & 0.11 & 0.71 \\
\hline 8.30 & 0.06 & 0.43 \\
\hline 10.96 & 0.05 & 0.32 \\
\hline
\end{tabular}

Wall thickness and composition are required for enrichment measurements. 


\subsubsection{Uranium Nitrate (HEU)}

Description: Solution in 0.1-2 liter plastic bottles; Q: $200 \mathrm{~g}{ }^{235} \mathrm{U} /$ liter.

Ranking:

\begin{tabular}{|c|c|c|c|}
\hline Property & \multicolumn{3}{|c|}{ Increasing Confidence $\rightarrow$} \\
\hline & Single & Cor & tion \\
\hline $\begin{array}{l}\text { Gamma-ray spectrum } \\
\text { (LRGS) }\end{array}$ & $\mathrm{X}$ & & \\
\hline $\begin{array}{l}\text { Gamma-ray spectrum } \\
\text { (HRGS) }\end{array}$ & $\mathbf{X}$ & $\mathrm{X}$ & $\mathrm{X}$ \\
\hline $\begin{array}{l}\text { Coincident neutron count- } \\
\text { ing rate (active) }\end{array}$ & & & $X$ \\
\hline $\begin{array}{l}\text { Gamma-ray transmission } \\
\text { ratio }\end{array}$ & & $\mathrm{X}$ & \\
\hline
\end{tabular}

\section{Discussion:}

Appearance - The color depends on the acid concentration and the valence state of the uranium. In dilute acid the colors are: U III - red, U IV - green, U V - red to muddy brown, and U VI - yellow. U VI is the most stable valence state.

Neutron - $\quad$ Neutron emission from active interrogation using subthreshold neutrons is due primarily to ${ }^{235} U$. Calculated passive neutron yields from $\mathrm{O}(\alpha, \mathrm{n})$ reactions and spontaneous fission are approximately:

\begin{tabular}{|c|c|c|c|c|}
\hline & wt $\%$ & {$[\mathrm{n} / \mathrm{sec}-\mathrm{kg}(\mathrm{U})]$} & wt $\%$ & [n/sec-kg (U) \\
\hline${ }^{234} \mathrm{U}:$ & 0.15 & 8. & 0.6 & 32. \\
\hline${ }^{235} \mathrm{U}:$ & 20. & 0.3 & 90. & 1.2 \\
\hline${ }^{238} \mathrm{U}:$ & 80. & 11. & 9. & 1.3 \\
\hline & & 19. & & 35 \\
\hline
\end{tabular}


Gamma ray - Sample homogeneity can be ensured in solution samples by mixing. The K-absorption edge is at $115.6 \mathrm{keV}$, and may be useful depending on sample containment and concentration. Wall thickness and composition are required for enrichment measurements. Solution thicknesses for $50 \%$ and $1 \%$ transmissions of $186 \mathrm{keV}$ gamma rays $(\mu \mathrm{e}$ assumed to be $0.45 \mathrm{~cm}^{-1}$ ) are $1.5 \mathrm{~cm}$ and $10 \mathrm{~cm}$, respectively. 


\subsection{4 $\mathrm{UF}_{6}, \mathrm{UF}_{4}(\mathrm{HEU})$}

Description: $\mathrm{UF}_{6}$ solid/solution in stainless steel cylinder,

8-15 kg ${ }^{23} \mathrm{U} / \mathrm{batch}$;

$\mathrm{UF}_{4}$ solid in $\mathrm{Al}$ can, $4-8 \mathrm{~kg}{ }^{235} \mathrm{U} / \mathrm{batch}$;

theoretical $\varrho: \mathrm{UF}_{6}-4.7 \mathrm{~g} / \mathrm{cm}^{3} ; \mathrm{UF}_{4}-6.7 \mathrm{~g} / \mathrm{cm}^{3}$;

color of solid: $\mathrm{UF}_{6}$ - colorless; $\mathrm{UF}_{4}-$ green.

\section{Ranking:}

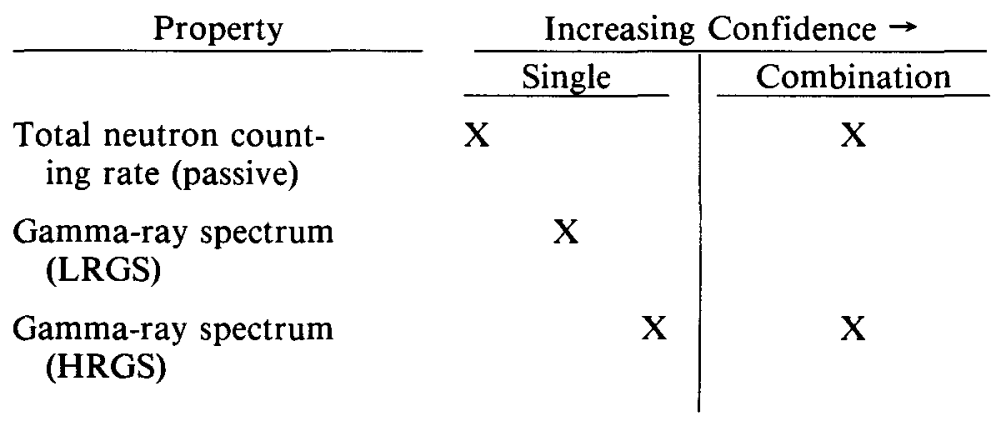

\section{Discussion:}

Neutron -

The dominant source of neutrons is the ${ }^{19} \mathrm{~F}(\alpha, \mathrm{n})$ reaction induced by the alpha particles from ${ }^{234} \mathrm{U}$. Calculated passive neutron yield for nonmultiplying, solid $\mathrm{UF}_{6}$ is approximately:

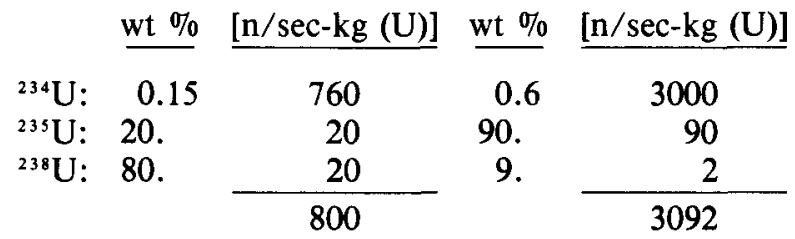

For $\mathrm{UF}_{4}$, the corresponding yields will be $\sim 85 \%$ of the above. Multiplication will be less than the same quantity of uranium as the oxide. 
Gamma ray - Thickness of $\mathrm{UF}_{6}$ for $50 \%$ and $1 \%$ transmissions of $186 \mathrm{keV}$ gamma rays is:

\begin{tabular}{|c|c|c|}
\hline $\begin{array}{c}\varrho \\
\left(\mathrm{g} / \mathrm{cm}^{3}\right)\end{array}$ & $\begin{array}{c}x(50 \%) \\
(\mathrm{cm})\end{array}$ & $\begin{array}{c}x(1 \%) \\
(\mathrm{cm})\end{array}$ \\
\hline 2.0 & 0.34 & 2.3 \\
\hline 3.0 & 0.23 & 1.5 \\
\hline 4.7 & 0.14 & 1.0 \\
\hline
\end{tabular}

Container wall attenuation is required for enrichment measurements. LRGS may be unsuitable for recycled uranium. 


\subsubsection{UAl $\mathbf{x}$ (HEU)}

Description: MTR elements, cermet, or alloy;

$170-400 \mathrm{~g}{ }^{235} \mathrm{U} /$ batch;

Q: $\sim 3.0-3.6 \mathrm{~g} / \mathrm{cm}^{3}$.

Ranking:

\begin{tabular}{|c|c|c|c|}
\hline Property & \multicolumn{3}{|c|}{ Increasing Confidence $\rightarrow$} \\
\hline & Single & Com & tion \\
\hline $\begin{array}{l}\text { Total neutron count- } \\
\text { ing rate (passive) }\end{array}$ & $\mathrm{X}$ & & $\mathrm{X}$ \\
\hline $\begin{array}{l}\text { Gamma-ray spectrum } \\
\text { (LRGS) }\end{array}$ & $X$ & & \\
\hline $\begin{array}{l}\text { Gamma-ray spectrum } \\
\text { (HRGS) }\end{array}$ & $X$ & $\mathrm{X}$ & $\mathrm{X}$ \\
\hline $\begin{array}{l}\text { Coincident neutron count- } \\
\text { ing rate (active) }\end{array}$ & $\mathrm{X}$ & $\mathrm{X}$ & $\mathrm{X}$ \\
\hline
\end{tabular}

\section{Discussion:}

Neutron -

The neutron yields depend on the uranium isotopic composition. The approximate emission rates for $1 \mathrm{~kg}$ of uranium in $\mathrm{UAI}_{\mathrm{X}}$ that is $20 \mathrm{wt} \%$ $\mathrm{U}$ are:

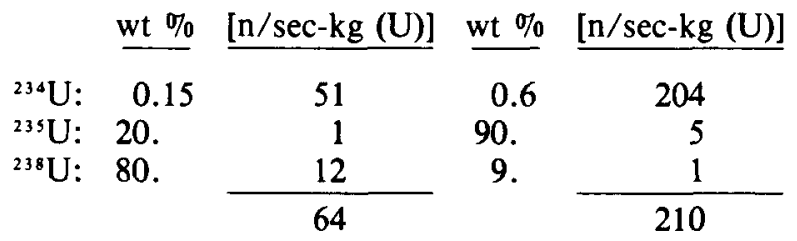

The response to subthreshold neutron interrogation will be primarily due to odd-numbered uranium isotopes. Multiplication is small and can be ignored. 
Gamma ray - Thicknesses of $\mathrm{UAl}_{\mathrm{X}}$ for $50 \%$ and $1 \%$ transmissions of $186 \mathrm{keV}$ gamma ray for different wt $\% \mathrm{U}$ in $\mathrm{UAl}_{\mathrm{X}}$ are:

\begin{tabular}{|c|c|c|c|}
\hline $\begin{array}{c}\text { Uranium } \\
\text { (wt \%) }\end{array}$ & $\begin{array}{c}\varrho \text { (assumed) } \\
\left(\mathrm{g} / \mathrm{cm}^{3}\right)\end{array}$ & $\begin{array}{c}\mathrm{x}(50 \%) \\
(\mathrm{cm})\end{array}$ & $\begin{array}{c}x(1 \%) \\
(\mathrm{cm})\end{array}$ \\
\hline 10 & 3.0 & 0.91 & 6.0 \\
\hline 20 & 3.3 & 0.54 & 3.6 \\
\hline 30 & 3.6 & 0.37 & 2.4 \\
\hline
\end{tabular}




\subsubsection{UAI $\mathbf{x}$ (HEU)}

Description: Recyclable scrap, $<2 \mathrm{~kg}{ }^{235} \mathrm{U} /$ batch.

\section{Ranking:}

\begin{tabular}{lll|lc}
\multicolumn{1}{c}{ Property } & & \multicolumn{3}{c}{ Increasing Confidence $\rightarrow$} \\
\cline { 2 - 3 } $\begin{array}{l}\text { Total neutron count- } \\
\text { ing rate (passive) }\end{array}$ & $\mathrm{X}$ & & & $\mathrm{X}$ \\
$\begin{array}{l}\text { Gamma-ray spectrum } \\
\text { (LRGS) }\end{array}$ & $\mathrm{X}$ & & & \\
$\begin{array}{l}\text { Gamma-ray spectrum } \\
\text { (HRGS) }\end{array}$ & $\mathrm{X}$ & $\mathrm{X}$ & $\mathrm{X}$ \\
$\begin{array}{l}\text { Coincident neutron count- } \\
\text { ing rate (active) }\end{array}$ & & $\mathrm{X}$ & $\mathrm{X}$ & $\mathrm{X}$
\end{tabular}

\section{Discussion:}

Neutron -

The neutron yields depend on the uranium isotopic composition. The approximate emission rates for $1 \mathrm{~kg}$ of uranium in $\mathrm{UAl}_{\mathrm{X}}$ that is $20 \mathrm{wt} \%$ $\mathrm{U}$ are:

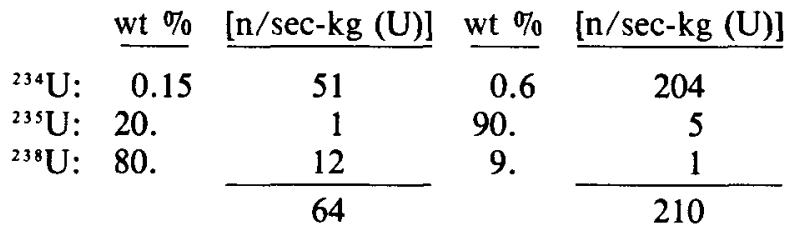

The response to subthreshold neutron interrogation will be primarily due to odd-numbered uranium isotopes. Multiplication is small and can generally be ignored.

Gamma ray - Thicknesses of $\mathrm{UAl}_{\mathrm{X}}$ for $50 \%$ and $1 \%$ transmissions of $186 \mathrm{keV}$ gamma ray for different wt \% U in $\mathrm{UAl}_{\mathrm{X}}$ are:

\begin{tabular}{|c|c|c|c|}
\hline $\begin{array}{l}\text { Uranium } \\
\text { (wt \%) }\end{array}$ & $\begin{array}{c}e \text { (assumed) } \\
\left(\mathrm{g} / \mathrm{cm}^{3}\right) \\
\end{array}$ & $\begin{array}{l}\times(50 \%) \\
(\mathrm{cm}) \\
\end{array}$ & $\begin{array}{c}x(1 \%) \\
(\mathrm{cm})\end{array}$ \\
\hline 10 & 3.0 & 0.91 & 6.0 \\
\hline 20 & 3.3 & 0.54 & 3.6 \\
\hline 30 & 3.6 & 0.37 & 2.4 \\
\hline
\end{tabular}




\subsubsection{UAl $\mathbf{X}(\mathrm{HEU})$}

Description: Extruded cores, fuel rod elements, $<30 \mathrm{wt} \% \mathrm{U}$; $40-80 \mathrm{~g}{ }^{235} \mathrm{U} /$ batch.

Ranking:

\begin{tabular}{|c|c|c|c|}
\hline Property & \multicolumn{3}{|c|}{ Increasing Confidence $\rightarrow$} \\
\hline & Single & Con & \\
\hline $\begin{array}{l}\text { Total neutron count- } \\
\text { ing rate (passive) }\end{array}$ & $\mathrm{X}$ & & $\mathrm{X}$ \\
\hline $\begin{array}{l}\text { Gamma-ray spectrum } \\
\text { (LRGS) }\end{array}$ & $\mathrm{X}$ & & \\
\hline $\begin{array}{l}\text { Gamma-ray spectrum } \\
\text { (HRGS) }\end{array}$ & $\mathrm{X}$ & $\mathrm{X}$ & $\mathrm{X}$ \\
\hline $\begin{array}{l}\text { Coincident neutron count- } \\
\text { ing rate (active) }\end{array}$ & & $\mathrm{X}$ & $\mathrm{X}$ \\
\hline
\end{tabular}

\section{Discussion:}

Neutron - $\quad$ The neutron yields depend on the uranium isotopic composition. The approximate emission rates for $1 \mathrm{~kg}$ of uranium in $\mathrm{UAl}_{\mathrm{X}}$ that is $20 \mathrm{wt} \%$ $\mathrm{U}$ are:

$\begin{array}{llcccc} & \frac{w t}{\text { wt } \%} & & {[\mathrm{n} / \mathrm{sec}-\mathrm{kg}(\mathrm{U})]} & \text { wt } \% & {[\mathrm{n} / \mathrm{sec}-\mathrm{kg}(\mathrm{U})]} \\ { }^{234} \mathrm{U}: & 0.15 & 51 & 0.6 & 204 \\ { }^{235} \mathrm{U}: & 20 . & 1 & 90 . & 5 \\ { }^{238} \mathrm{U}: & 80 . & 12 & 9 . & 1 \\ & 64 & & 210\end{array}$

The response to subthreshold neutron interrogation will be primarily due to odd-numbered uranium isotopes. Multiplication is small and can be ignored.

Gamma ray - Thicknesses of $\mathrm{UAl}_{\mathrm{X}}$ for $50 \%$ and $1 \%$ transmissions of $186 \mathrm{keV}$ gamma ray for different wt $\% \mathrm{U}$ in $\mathrm{UAl}_{\mathrm{X}}$ are:

\begin{tabular}{|c|c|c|c|}
\hline $\begin{array}{l}\text { Uranium } \\
\text { (wt \%) }\end{array}$ & $\begin{array}{c}\varrho \text { (assumed) } \\
\left(\mathrm{g} / \mathrm{cm}^{3}\right)\end{array}$ & $\begin{array}{c}\mathrm{x}(50 \%) \\
(\mathrm{cm}) \\
\end{array}$ & $\begin{array}{c}x(1 \%) \\
(\mathrm{cm})\end{array}$ \\
\hline 10 & 3.0 & 0.91 & 6.0 \\
\hline 20 & 3.3 & 0.54 & 3.6 \\
\hline 30 & 3.6 & 0.37 & 2.4 \\
\hline
\end{tabular}




\subsubsection{UAI $\mathrm{I}_{\mathrm{X}}$ (HEU)}

Description: Billets, Al cladding, $<30$ wt $\% \mathrm{U}$;

$\sim 100 \mathrm{~g}{ }^{235} \mathrm{U} /$ batch.

\section{Ranking:}

\begin{tabular}{|c|c|c|c|}
\hline Property & \multicolumn{3}{|c|}{ Increasing Confidence $\rightarrow$} \\
\hline & Single & Col & nation \\
\hline $\begin{array}{l}\text { Total neutron count- } \\
\text { ing rate (passive) }\end{array}$ & $\mathrm{X}$ & & $\mathrm{X}$ \\
\hline $\begin{array}{l}\text { Gamma-ray spectrum } \\
\text { (LRGS) }\end{array}$ & $\mathrm{X}$ & & \\
\hline $\begin{array}{l}\text { Gamma-ray spectrum } \\
\text { (HRGS) }\end{array}$ & $X$ & $\mathbf{X}$ & $\mathrm{X}$ \\
\hline $\begin{array}{l}\text { Coincident neutron count- } \\
\text { ing rate (active) }\end{array}$ & 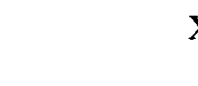 & $\mathrm{X}$ & $\mathrm{X}$ \\
\hline
\end{tabular}

\section{Discussion:}

Neutron -

The neutron yields depend on the uranium isotopic composition. The approximate emission rates for $1 \mathrm{~kg}$ of uranium in $\mathrm{UAl}_{\mathrm{X}}$ that is $20 \mathrm{wt} \%$ $\mathrm{U}$ are:

$\begin{array}{lccccc} & \text { wt \% } & \text { [n/sec-kg (U)] } & \text { wt \% } & \text { [n/sec-kg (U)] } \\ { }^{234} \mathrm{U}: & 0.15 & 51 & 0.6 & 204 \\ { }^{235} \mathrm{U}: & 20 . & 1 & 90 . & 5 \\ { }^{238} \mathrm{U}: & 80 . & 12 & & 9 . & \frac{1}{210}\end{array}$

The response to subthreshold neutron interrogation will be primarily due to odd-numbered uranium isotopes. Multiplication is small and can be ignored.

Gamma ray - Thicknesses of $\mathrm{UAl}_{\mathrm{X}}$ for $50 \%$ and $1 \%$ transmissions of $186 \mathrm{keV}$ gamma ray for different wt $\% \mathrm{U}$ in $\mathrm{UAl}_{\mathrm{X}}$ are:

\begin{tabular}{|c|c|c|c|}
\hline $\begin{array}{c}\text { Uranium } \\
\text { (wt } \% \text { ) }\end{array}$ & $\begin{array}{c}Q \text { (assumed) } \\
\left(\mathrm{g} / \mathrm{cm}^{3}\right)\end{array}$ & $\begin{array}{c}x(50 \%) \\
(\mathrm{cm})\end{array}$ & $\begin{array}{c}x(1 \%) \\
(\mathrm{cm})\end{array}$ \\
\hline 10 & 3.0 & 0.91 & 6.0 \\
\hline 20 & 3.3 & 0.54 & 3.6 \\
\hline 30 & 3.6 & 0.37 & 2.4 \\
\hline
\end{tabular}




\subsection{Plutonium/Uranium}

\subsubsection{Pu/U (HEU)}

Description: Platelet, stainless steel cladding; $<200 \mathrm{~g} \mathrm{Pu} /$ batch.

Ranking:

\begin{tabular}{|c|c|c|c|c|c|c|c|}
\hline \multirow[b]{3}{*}{$\begin{array}{l}\text { Total neutron count- } \\
\text { ing rate (passive) }\end{array}$} & \multicolumn{7}{|c|}{ Increasing Confidence $\rightarrow$} \\
\hline & \multicolumn{2}{|c|}{ Single } & \multicolumn{5}{|c|}{ Combination } \\
\hline & $\mathrm{X}$ & & & & & & \\
\hline $\begin{array}{l}\text { Coincident neutron count- } \\
\text { ing rate (passive) }\end{array}$ & $\mathrm{X}$ & & $\mathrm{X}$ & & & & $\mathrm{X}$ \\
\hline $\begin{array}{l}\text { Gamma-ray spectrum } \\
\text { (HRGS) }\end{array}$ & $\mathrm{X}$ & & $\mathrm{X}$ & $X$ & $\mathrm{X}$ & $\mathrm{X}$ & $X$ \\
\hline Thermal power & & & & $\mathrm{X}$ & & $\mathrm{X}$ & $\mathrm{X}$ \\
\hline $\begin{array}{l}\text { Coincident neutron count- } \\
\text { ing rate (active) }\end{array}$ & & & & & $\mathrm{X}$ & $\mathrm{X}$ & $\mathrm{X}$ \\
\hline
\end{tabular}

\section{Discussion:}

Neutron - $\quad$ Neutron yields depend on the plutonium and uranium isotopic compositions. The neutron yields from a passive measurement will be primarily from the plutonium (see Table 4, p. 31). With active interrogation using subthreshold neutrons, induced fissions in ${ }^{239} \mathrm{Pu},{ }^{241} \mathrm{Pu}$, and ${ }^{235} \mathrm{U}$ are the primary sources of neutrons.

Gamma ray - The presence of the $186 \mathrm{keV}$ gamma ray from ${ }^{235} \mathrm{U}$ is the main indicator of uranium in a plutonium sample.

Thermal power - The thermal power results primarily from the decay of the plutonium in the sample. 


\subsection{2 $\mathrm{PuO}_{2} / \mathrm{UO}_{2}$}

Description: Powder in cans; $0.2-5 \mathrm{~kg} \mathrm{Pu} /$ batch.

Pellets (few grams each); $\sim 1 \mathrm{~kg} \mathrm{Pu} /$ batch.

Pins in metal sheaths; $15-250 \mathrm{~g} \mathrm{Pu} /$ batch.

Assemblies of pins; $2-4 \mathrm{~kg} \mathrm{Pu} / \mathrm{batch}$.

Ranking:

\begin{tabular}{|c|c|c|c|c|c|c|}
\hline Property & \multicolumn{6}{|c|}{ Increasing Confidence $\rightarrow$} \\
\hline & \multicolumn{2}{|c|}{ Single } & \multicolumn{4}{|c|}{ Combination } \\
\hline $\begin{array}{l}\text { Total neutron count- } \\
\text { ing rate (passive) }\end{array}$ & $\mathrm{X}$ & & & & & \\
\hline $\begin{array}{l}\text { Coincident neutron count- } \\
\text { ing rate (passive) }\end{array}$ & $X$ & & $\mathrm{X}$ & & $X$ & $\mathrm{X}$ \\
\hline $\begin{array}{l}\text { Gamma-ray spectrum } \\
\text { (HRGS) }\end{array}$ & & $\mathrm{X}$ & $\mathrm{X}$ & $\mathrm{X}$ & $\mathrm{X}$ & $\mathrm{X}$ \\
\hline Thermal power & & & & $\mathrm{X}$ & $X$ & $\mathrm{X}$ \\
\hline $\begin{array}{l}\text { Coincident neutron count- } \\
\text { ing rate (active) }\end{array}$ & & & & & & $\mathrm{X}$ \\
\hline
\end{tabular}

\section{Discussion:}

Neutron - $\quad$ The passive neutron yield will be primarily due to the plutonium component (see Table 4,p.31). The uranium component and its isotopic composition must be considered in the multiplication corrections. The neutrons emitted in active interrogation with subthreshold neutrons are due to ${ }^{239} \mathrm{Pu},{ }^{2+1} \mathrm{Pu}$ and ${ }^{235} \mathrm{U}$ fissioning.

Gamma ray - Interferences with the gamma rays used for plutonium isotopic measurements will depend on the isotopic composition of the uranium.

Thermal power - The thermal power results primarily from the decay of the plutonium in the sample. 


\subsection{3 $\mathrm{PuO}_{2} / \mathrm{UO}_{2}$ (HEU)}

Description: Scrap in a variety of matrices contained in $\sim 1$ liter cans; 0.05-3 kg Pu/batch.

\section{Ranking:}

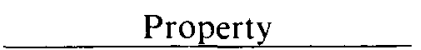

Total neutron counting rate (passive)

Coincident neutron counting rate (passive)

Gamma-ray spectrum (HRGS)

Thermal power

Coincident neutron counting rate (active)

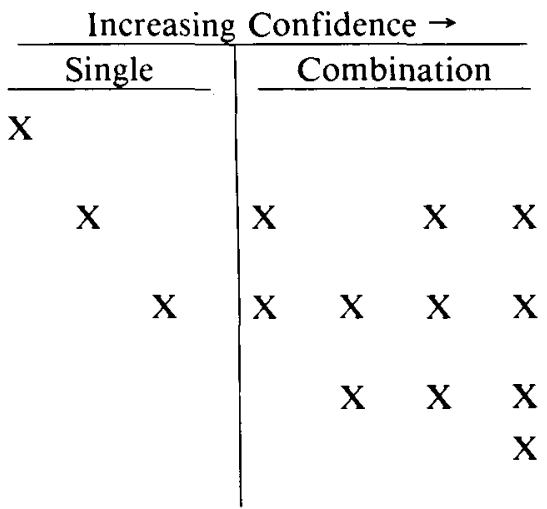

\section{Discussion:}

Neutron -

The passive neutron yield will be primarily due to the plutonium component. The uranium component and its isotopic composition must be considered in the multiplication corrections. Neutrons emitted during active interrogation with subthreshold neutrons are essentially from fissioning of ${ }^{239} \mathrm{Pu},{ }^{241} \mathrm{Pu}$ and ${ }^{235} \mathrm{U}$.

Gamma ray - Interferences with the gamma rays used for plutonium isotopic measurements will depend on the isotopic composition of the uranium.

Thermal power - The thermal power results primarily from the decay of the plutonium in the sample. 


\section{Nuclear Data for Verification Measurements}

This section contains information on the neutron, gamma-ray, and thermal properties of plutonium and uranium and supplements the earlier sections of the Handbook. References for the data presented in this section are given in the Appendix.

\subsection{Plutonium}

The properties of plutonium samples are dependent on the plutonium isotopic composition. Examples presented in this section use the isotopic compositions in Table 2.

\section{TABLE 2 - PLUTONIUM ISOTOPIC ABUNDANCES FOR DIFFERENT BURNIJPS}

\begin{tabular}{|c|c|c|c|c|c|}
\hline $\begin{array}{c}\text { Burnup } \\
(1000 \mathrm{MWD} / \mathrm{t})\end{array}$ & $\begin{array}{c}{ }^{238} \mathrm{Pu} \\
(\text { wt } \%)\end{array}$ & $\begin{array}{l}{ }^{239} \mathrm{Pu} \\
\text { (wt \%) }\end{array}$ & $\begin{array}{r}{ }^{240} \mathrm{Pu} \\
(\text { wt } \%)\end{array}$ & $\begin{array}{l}{ }^{24 !} \mathrm{Pu} \\
(\text { wt } \% 0)\end{array}$ & $\begin{array}{l}{ }^{24} \mathrm{Pu} \\
(\text { wt } \% \text { ) } \\
\end{array}$ \\
\hline Low & 0.01 & 93. & 6. & 0.5 & 0.04 \\
\hline $8-10$ & 0.10 & 87. & 10. & 2.4 & 0.30 \\
\hline $16-18$ & 0.25 & 75. & 18. & 4.5 & 1.0 \\
\hline $25-27$ & 1.0 & 58. & 25. & 9.0 & 7.0 \\
\hline $38-40$ & 2.0 & 45. & 27. & 15.0 & 12.0 \\
\hline
\end{tabular}

The data in Table 2 are approximate values for Light Water Reactors. Isotopic abundances for other reactor types may be somewhat different.

Half-lives for the plutonium isotopes in Table 2 and other selected isotopes are listed in Table 3. Americium-241, a decay product of ${ }^{241} \mathrm{Pu}$, is included because its presence increases the $\alpha$-activity in a sample. This increase in $\alpha$-activity can be a significant factor for neutron yields and thermal outputs of plutonium samples. The curium and californium isotopes are included in Table 3 because their presence in a sample could also significantly affect neutron yields and thermal output. 


\section{TABLE 3 - HALF-LIVES OF SELECTED ISOTOPES}

\begin{tabular}{|c|c|c|c|}
\hline Isotope & $\begin{array}{c}\text { Half-Life } \\
(\mathrm{yr})\end{array}$ & Isotope & $\begin{array}{l}\text { Half-Life } \\
(\mathrm{yr})\end{array}$ \\
\hline${ }^{238} \mathrm{Pu}$ & $8.77 \times 10^{1}$ & ${ }^{241} \mathrm{Am}$ & $4.34 \times 10^{2}$ \\
\hline${ }^{239} \mathrm{Pu}$ & $2.41 \times 10^{4}$ & ${ }^{242} \mathrm{Cm}$ & $4.46 \times 10^{-1}$ \\
\hline${ }^{240} \mathrm{Pu}$ & $6.56 \times 10^{3}$ & ${ }^{244} \mathrm{Cm}$ & $1.81 \times 10^{1}$ \\
\hline${ }^{24} \mathrm{Pu}$ & $1.44 \times 10^{1}$ & ${ }^{252} \mathrm{Cf}$ & 2.64 \\
\hline${ }^{242} \mathrm{Pu}$ & $3.76 \times 10^{s}$ & & \\
\hline
\end{tabular}

\subsubsection{Neutron Properties}

Neutrons emitted by plutonium samples are essentially from spontaneous fission, $(\alpha, \mathrm{n})$ reactions with low- $Z$ elements, and neutroninduced fission. Table 4 lists spontaneous fission neutron yields for nonmultiplying samples. Note that the spontaneous fission yields for the odd-numbered plutonium isotopes are very small in comparison with those for the even-numbered isotopes. Note, also, the rather large specific spontaneous fission yields for ${ }^{242} \mathrm{Cm},{ }^{244} \mathrm{Cm}$, and ${ }^{252} \mathrm{Cf}$. (Although the ${ }^{252} \mathrm{Cf}$ yield is shown for a $1 \mathrm{~g}$ sample, typical sample sizes are in the $\mu \mathrm{g}$ to $\mathrm{mg}$ range.)

$\mathrm{PuO}_{2}, \mathrm{PuF}_{4}$, and $\mathrm{PuAl}_{\mathrm{X}}$ are materials frequently encountered in the nuclear industry. Their yields and the corresponding yields for americium and curium are included in Table 4. Neutron yields from the $\operatorname{Be}(\alpha, n)$ reaction are high in comparison to yields from $(\alpha, n)$ reactions with other elements. These have also been included in the table because the presence of beryllium in a sample could cause measurement interference. The beryllium data are for a thick beryllium target; i.e., the beryllium to plutonium atom ratio is $>1$.

The $(\alpha, \mathrm{n})$ yields in Table 4 were calculated from thick target yields given in Table 5. In cases where the target is not thick (e.g., oxygen, fluorine, and aluminum), it was necessary to reduce the thick target yields to account for the presence of plutonium. The reduction factor is given approximately by:

$$
K=\left(1+\frac{S_{\alpha} N_{\alpha}}{S_{t} N_{t}}\right)^{-1}
$$


TABLE 4 - NEUTRON YIELDS FOR SELECTED ISOTOPES

Yields ( $\mathrm{n} / \mathrm{sec}-\mathrm{g}$ of isotope)

\begin{tabular}{|c|c|c|c|c|c|}
\hline \multirow[b]{2}{*}{ Isotope } & \multirow{2}{*}{$\begin{array}{c}\text { Spontaneous } \\
\text { Fission }\end{array}$} & \multicolumn{4}{|c|}{$(\alpha, \mathrm{n})$ Reactions $^{\mathrm{a}}$} \\
\hline & & Oxygen & Fluorine & Aluminum & Beryllium \\
\hline${ }^{238} \mathrm{Pu}$ & $2.6 \times 10^{3}$ & $1.5 \times 10^{4}$ & $2.8 \times 10^{6}$ & $4.1 \times 10^{5}$ & $5.0 \times 10^{7}$ \\
\hline${ }^{239} \mathrm{Pu}$ & $2.3 \times 10^{-2}$ & $4.2 \times 10^{1}$ & $6.9 \times 10^{3}$ & $8.8 \times 10^{2}$ & $1.4 \times 10^{5}$ \\
\hline${ }^{240} \mathrm{Pu}$ & $9.9 \times 10^{2}$ & $1.5 \times 10^{2}$ & $2.5 \times 10^{4}$ & $3.3 \times 10^{3}$ & $5.1 \times 10^{5}$ \\
\hline${ }^{241} \mathrm{Pu}$ & 5. $\times 10^{-2} b$ & 1.4 & $2.1 \times 10^{2}$ & $2.0 \times 10^{1}$ & $4.7 \times 10^{3}$ \\
\hline${ }^{242} \mathrm{Pu}$ & $1.7 \times 10^{3}$ & 2.1 & $3.3 \times 10^{2}$ & $3.1 \times 10^{1}$ & $7.2 \times 10^{3}$ \\
\hline${ }^{241} \mathrm{Am}$ & $1.3^{b}$ & $2.9 \times 10^{3}$ & $5.5 \times 10^{5}$ & $8.1 \times 10^{4}$ & $9.8 \times 10^{6}$ \\
\hline${ }^{242} \mathrm{Cm}$ & $2.3 \times 10^{7}$ & $4.2 \times 10^{6}$ & $9.2 \times 10^{8}$ & $1.8 \times 10^{8}$ & $1.4 \times 10^{10}$ \\
\hline${ }^{244} \mathrm{Cm}$ & $1.1 \times 10^{7}$ & $8.5 \times 10^{4}$ & $1.8 \times 10^{7}$ & $2.8 \times 10^{6}$ & $2.9 \times 10^{8}$ \\
\hline${ }^{252} \mathrm{Cf}$ & $2.3 \times 10^{12}$ & $\mathrm{c}$ & c & $\mathrm{c}$ & $\mathrm{c}$ \\
\hline
\end{tabular}

The target to $\alpha$-emitter atom ratio for oxygen is 2 , and for fluorine it is 4 ; i.e., $\mathrm{PuO}_{2}, \mathrm{PuF}_{4}$, etc. For aluminum, the $\alpha$-emitter is $20 \mathrm{wt} \%$ of the alloy. The beryllium values are for a thick beryllium target.

$\mathrm{b}_{\text {Estimated. }}$

${ }^{c}$ This yield is $<0.1 \%$ of the spontaneous fission yield. 
where $S_{\alpha}$ and $S_{t}$ are the rates at which an $\alpha$-particle loses energy to the $\alpha$-emitter and target atoms, and $\mathrm{N}_{\alpha}$ and $\mathrm{N}_{\mathrm{t}}$ are the atom densities. Approximate values for the ratios $\mathrm{S}_{\alpha} / \mathrm{S}_{\mathrm{t}}$ are given in Table 6.

To illustrate this reduction in yield factor, for $\mathrm{PuO}_{2}$ it is:

$$
[1+3.8(1 / 2)]^{-1}=0.34
$$

The number of significant figures shown in Tables 4,5 , and 6 is not indicative of the accuracies of the values. In some cases the uncertainty is $\sim 3 \%$; in others it may be as high as $10-20 \%$.

The specific neutron yield for a nonmultiplying sample is given by:

$$
\mathrm{Y}=\sum_{\mathrm{i}} \mathrm{w}_{i}\left(\mathrm{Y}_{s F}+\mathrm{Y}_{\alpha, n}\right)_{i}
$$

where i refers to each $\alpha$-emitter, $w$ is the isotopic weight fraction, and $Y_{S F}$ and $Y_{\alpha, n}$ are the spontaneous fission and $(\alpha, n)$ neutron yields per gram of isotope.

In samples where neutron yields from $(\alpha, n)$ reactions are insignificant, the neutron yield is that for spontaneous fission.

Figure 1 illustrates the effect plutonium isotopic composition has on spontaneous fission yields for nonmultiplying samples. The isotopic compositions used for the calculations are those given in Table 2. Note how significant the ${ }^{242} \mathrm{Pu}$ contribution becomes with increasing burnup.

Figure 2 shows the total neutron yields (spontaneous fission $+[\alpha, \mathrm{n}]$ ) for nonmultiplying $\mathrm{PuO}_{2}$, using the same isotopic composition as Figure 1. This figure demonstrates the importance of the minor isotopic constituents for high burnup fuel.

Figure 3 is a plot of the total neutron yields for nonmultiplying $\mathrm{PuF}_{4}$. Note the ordinate scale is 100 times greater than those in Figures 1 and 2 . In this case, the total yields are dominated by the $F(\alpha, n)$ reaction. As in the preceding figures, the effect of increasing burnup on the yields is also shown. 
TABLE 5 - THICK TARGET $(\alpha, \mathrm{n})$ NEUTRON YIELDS FOR SELECTED ISOTOPES

Average alphaparticle energy $(\mathrm{MeV})$

Yields (n/10 $\alpha$-particles) ${ }^{\mathrm{a}}$

\section{9}

5.15

5.5

5.8

6.1

\begin{tabular}{|c|c|c|}
\hline Isotope & Lithium & Beryllium \\
\hline${ }^{241} \mathrm{Pu},{ }^{242} \mathrm{Pu}$ & 0.5 & 48 \\
\hline${ }^{239} \mathrm{Pu},{ }^{240} \mathrm{Pu}$ & 1.0 & 61 \\
\hline${ }^{238} \mathrm{Pu},{ }^{241} \mathrm{Am}$ & 2.1 & 79 \\
\hline${ }^{244} \mathrm{Cm}$ & 3.5 & 98 \\
\hline${ }^{242} \mathrm{Cm}$ & 5.6 & 116 \\
\hline
\end{tabular}

Boron Oxygen

Fluorine $\underline{\underline{\text { luminum }}}$

aTarget elements are of natural isotopic abundance.

$\begin{array}{rrrr}14 & 0.042 & 4.3 & 0.23 \\ 17 & 0.053 & 5.8 & 0.42 \\ 21 & 0.067 & 8.4 & 0.70 \\ 23 & 0.083 & 11.4 & 1.05 \\ 26 & 0.101 & 14.6 & 1.60\end{array}$

TABLE 6 - STOPPING POWER RATIOS BETWEEN PLUTONIUM AND VARIOUS ELEMENTS $\underline{\text { Lithium Beryllium Boron Oxygen Fluorine Aluminum }}$ $\underline{S_{\alpha}} \equiv \underline{\text { Stopping power ( } \alpha \text {-emitter) }}$

$\mathrm{S}_{\mathrm{t}}$ Stopping power (target)

10. 6.7 6.5 3.8 3.6 3.0 


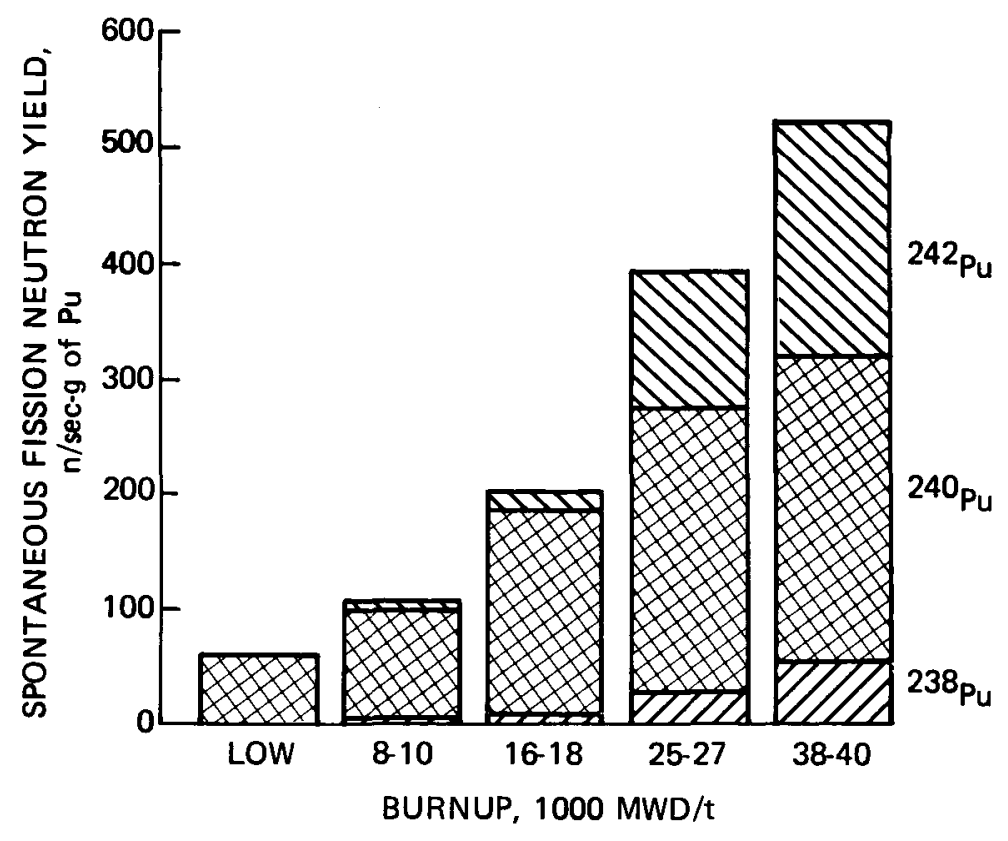

FIGURE 1 - Spontaneous fission neutron yields from nonmultiplying plutonium for the isotopic compositions in Table 2. 


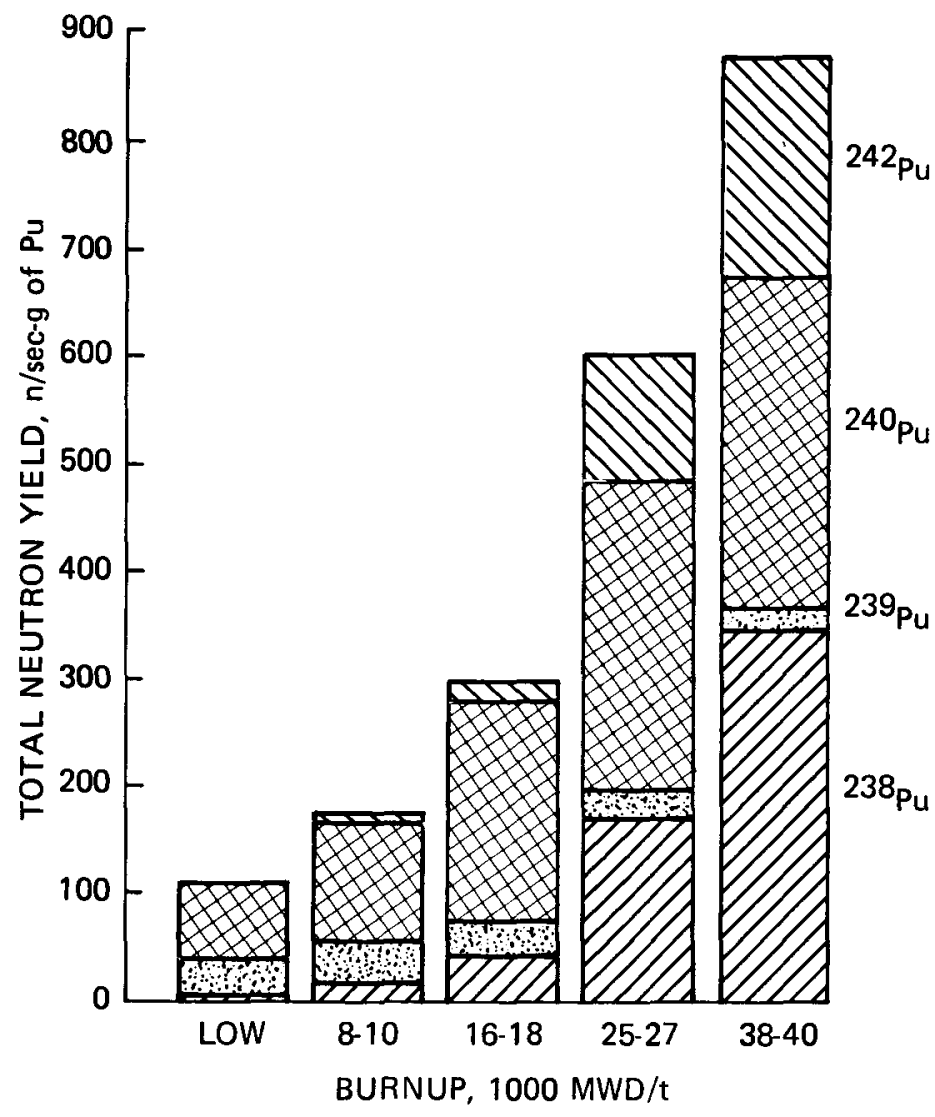

FIGURE 2 - Total neutron yields from nonmultiplying $\mathrm{PuO}_{2}$ for the isotopic compositions in Table 2. 


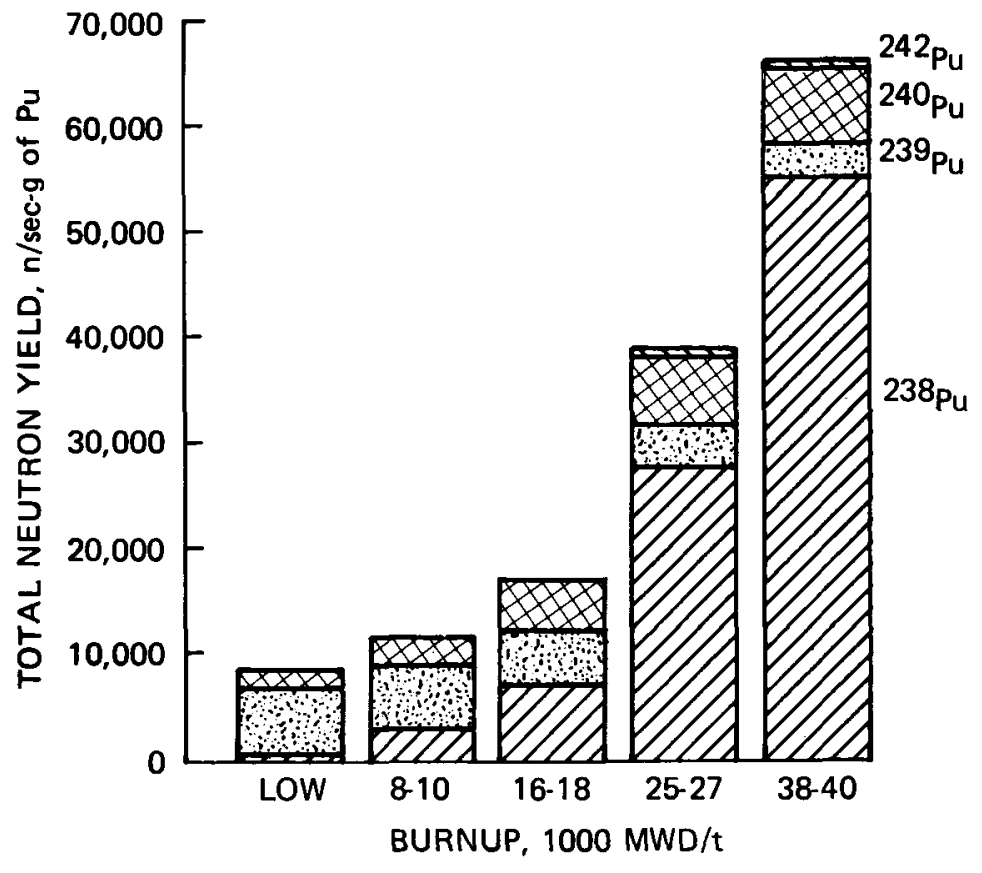

FIGURE 3 - Total neutron yields from nonmultiplying $\mathrm{PuF}_{4}$ for the isotopic compositions in Table 2. 
Figures 1-3 show neutron yields from plutonium isotopes, only. One of the plutonium daughters, ${ }^{241} \mathrm{Am}$, is important when determining neutron yields for samples in which $(\alpha, n)$ reactions are present. When ${ }^{24} \mathrm{Pu}$ decays by $\beta^{-}$emission (which it does $99.9976 \%$ of the time), the product is ${ }^{241} \mathrm{Am}$, an $\alpha$-emitter. The ingrowth of ${ }^{241} \mathrm{Am}$ results in the total neutron yield for a sample initially increasing with time. The total neutron yield (without multiplication) is given by:

$$
\begin{aligned}
\mathrm{Y}(\mathrm{t})= & \sum_{i=1} \mathrm{w}_{1}\left(\mathrm{Y}_{s F}+\mathrm{Y}_{\alpha, n}\right) \mathrm{e}^{-\lambda_{1} \mathrm{t}}+ \\
& w_{4}\left(\mathrm{Y}_{s+}+\mathrm{Y}_{a, n}\right) \frac{\lambda_{4}}{\lambda_{4}-\lambda_{6}}\left(\mathrm{e}^{-\lambda_{n} \mathrm{t}}-\mathrm{e}^{-\lambda_{4} \mathrm{t}}\right)
\end{aligned}
$$

where the subscripts $1-6$ refer to ${ }^{238} \mathrm{Pu},{ }^{239} \mathrm{Pu},{ }^{240} \mathrm{Pu},{ }^{241} \mathrm{Pu},{ }^{242} \mathrm{Pu}$, and ${ }^{24} \mathrm{Am}$, respectively; $\lambda=\ln 2 / \mathrm{T}_{1 / 2} ; \mathrm{T}_{1 / 2}$ is the half life; and $\mathrm{t}=0$ is the time when the ${ }^{241} \mathrm{Am}$ content is zero.

Figure 4 shows the variation in yields with time for $\mathrm{PuO}_{2}$ and $\mathrm{PuF}_{4}$ due to ${ }^{241} \mathrm{Am}$ ingrowth. (These curves will reach maxima at times dependent on the initial isotopic composition and the particular $(\alpha, n)$ reactions present.)

If neutrons are only from spontaneous fission, the variation in neutron yield is a slight $(<0.1 \% / y r)$ decrease for all burnups.

Neutron multiplication is the increase in neutron yield that results from secondary reactions, especially neutron-induced fission. A measure of sample multiplication is the ratio of actual neutron yield to what that yield would be if secondary reactions were not present. Unless multiplication is taken into account, either during system calibration or by calculation, results will be biased high. Multiplication is illustrated in Figure 5 where the increase in multiplication with plutonium mass can be seen. Figure 5 also shows that for a given plutonium mass, multiplication increases with sample density. The degree of multiplication depends on sample geometry; e.g., for a given mass and density the more closely a sample resembles a sphere, the higher will be its multiplication. Figure 6 shows calculated multiplication as a function of the height/diameter ratio. 


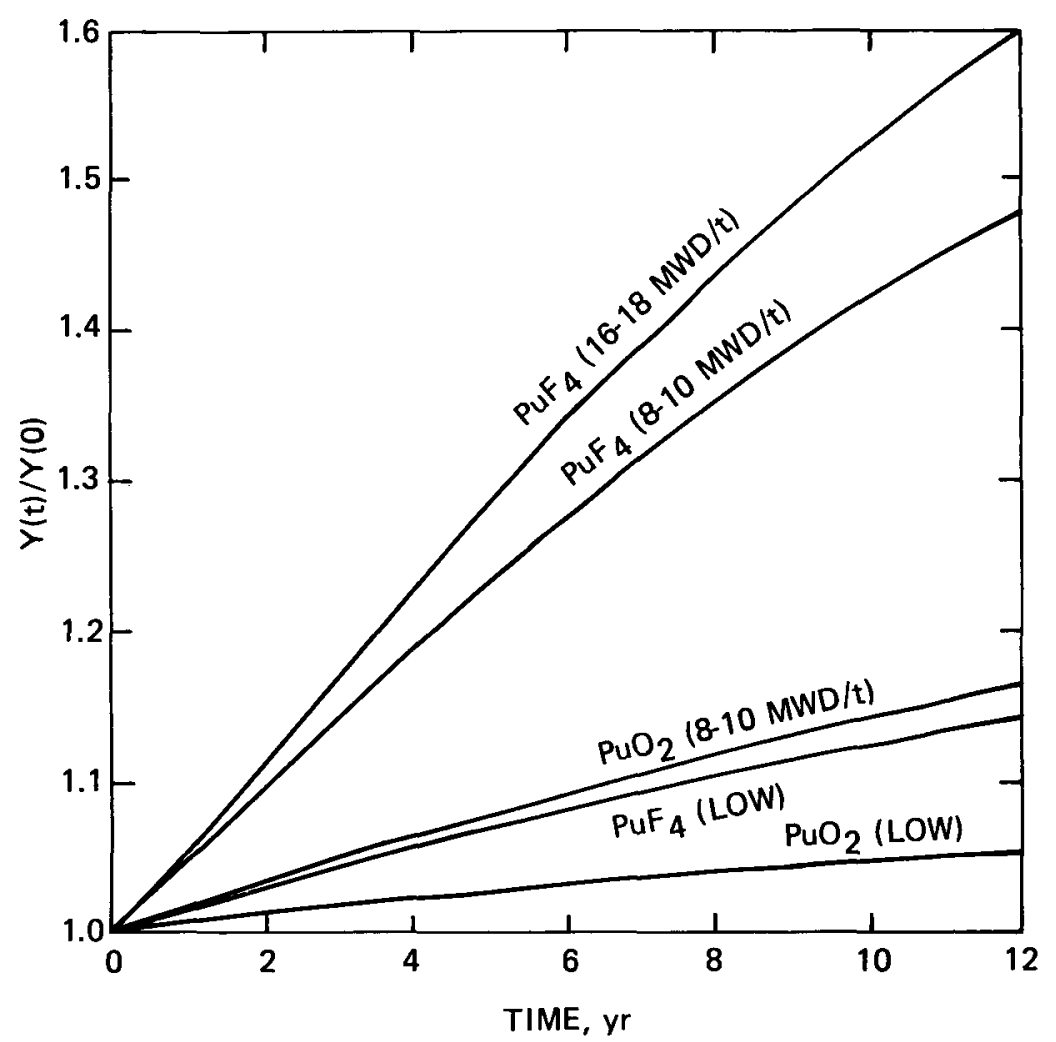

FIGURE 4 - Ratios of neutron yields at time $t$ relative to that at $t=0$, $\mathrm{Y}(\mathrm{t}) / \mathrm{Y}(0)$, for different sample types and isotopic compositions. Low, 8-10, and 16-18 MWD/t refer to the isotopic compositions for different burnups from Table 2. Curves for $\mathrm{PuO}_{2} 16-18,25-27$, and 38-40 MWD/t would fall close to the curve for $\mathrm{PuO}_{2} 8-10 \mathrm{MWD} / \mathrm{t}$. Curves for $\mathrm{PuF}_{4}$ 25-27 and 38-40 MWD/t would lie near the curve for $\mathrm{PuF}_{4}$ 8-10 MWD/t. 


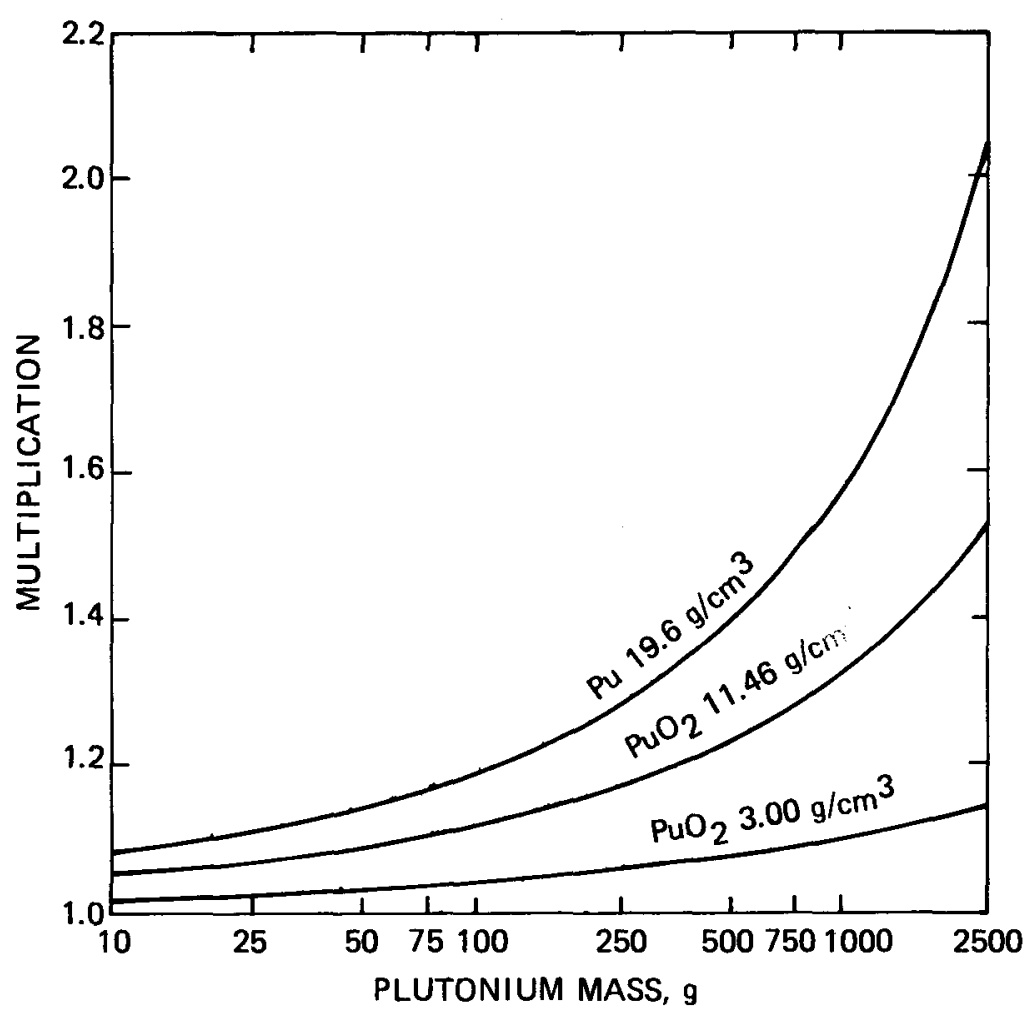

FIGURE 5 - Calculated multiplication for different plutonium samples composed of ${ }^{239} \mathrm{Pu}-90 \%$ and ${ }^{240} \mathrm{Pu}-10 \%$. Sample shape is a solid right cylinder; height is equal to diameter. 


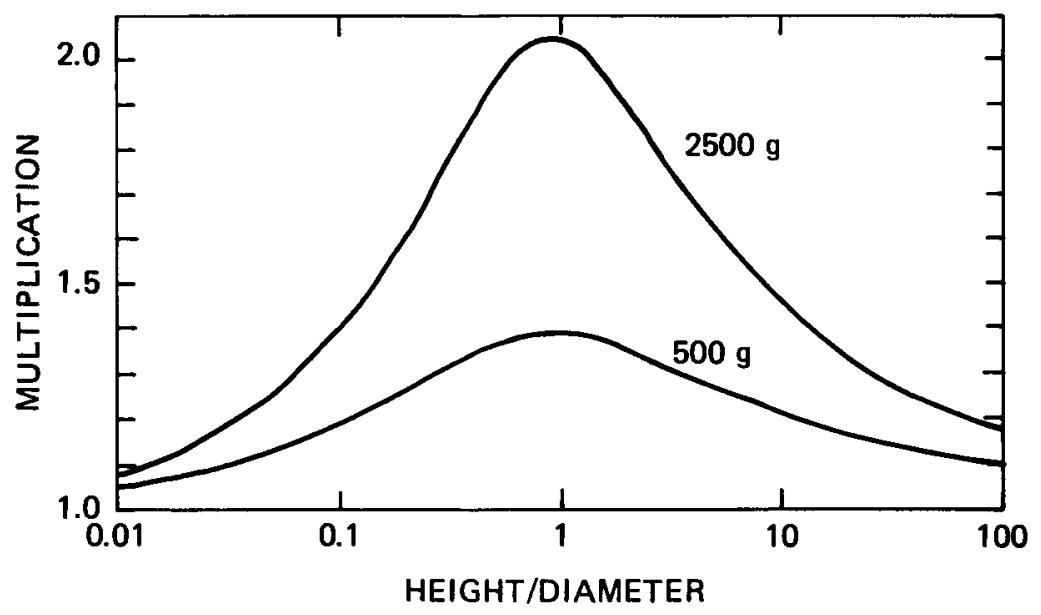

FIGURE 6 - Calculated multiplication as a function of the height/ diameter ratio for 500 and $2500 \mathrm{~g}$ of Pu metal in solid right cylinders; $\varrho=19.6 \mathrm{~g} / \mathrm{cm}^{3},{ }^{239} \mathrm{Pu}-90 \%$, and ${ }^{240} \mathrm{Pu}-10 \%$.

In addition to neutrons emitted spontaneously from a sample, neutrons from induced fission can be used to deduce information about a sample. Active assay using neutron interrogation usually employs the $(\mathrm{n}, \mathrm{f})$ reaction. Cross sections for this reaction are shown in Figure 7 for plutonium for neutron energies $<2 \mathrm{MeV}$. Note the different shapes for the odd- and even-numbered isotopes. Cross sections for thermal neutrons $(0.025 \mathrm{eV})$ are given in Table 7 . Observe, especially, the high values for the odd-numbered plutonium isotopes.

If a ${ }^{238} \mathrm{Pu}-\mathrm{Li}(\alpha, \mathrm{n})$ source is used as the interrogation source, most of the interrogation neutrons will be subthreshold (energies below the drop-offs in Figure 7), and the active NDA system response will be primarily from odd-numbered plutonium isotopes. Figure 8 is a spectrum for an unmoderated ${ }^{238} \mathrm{Pu}-\operatorname{Li}(\alpha, \mathrm{n})$ source. 

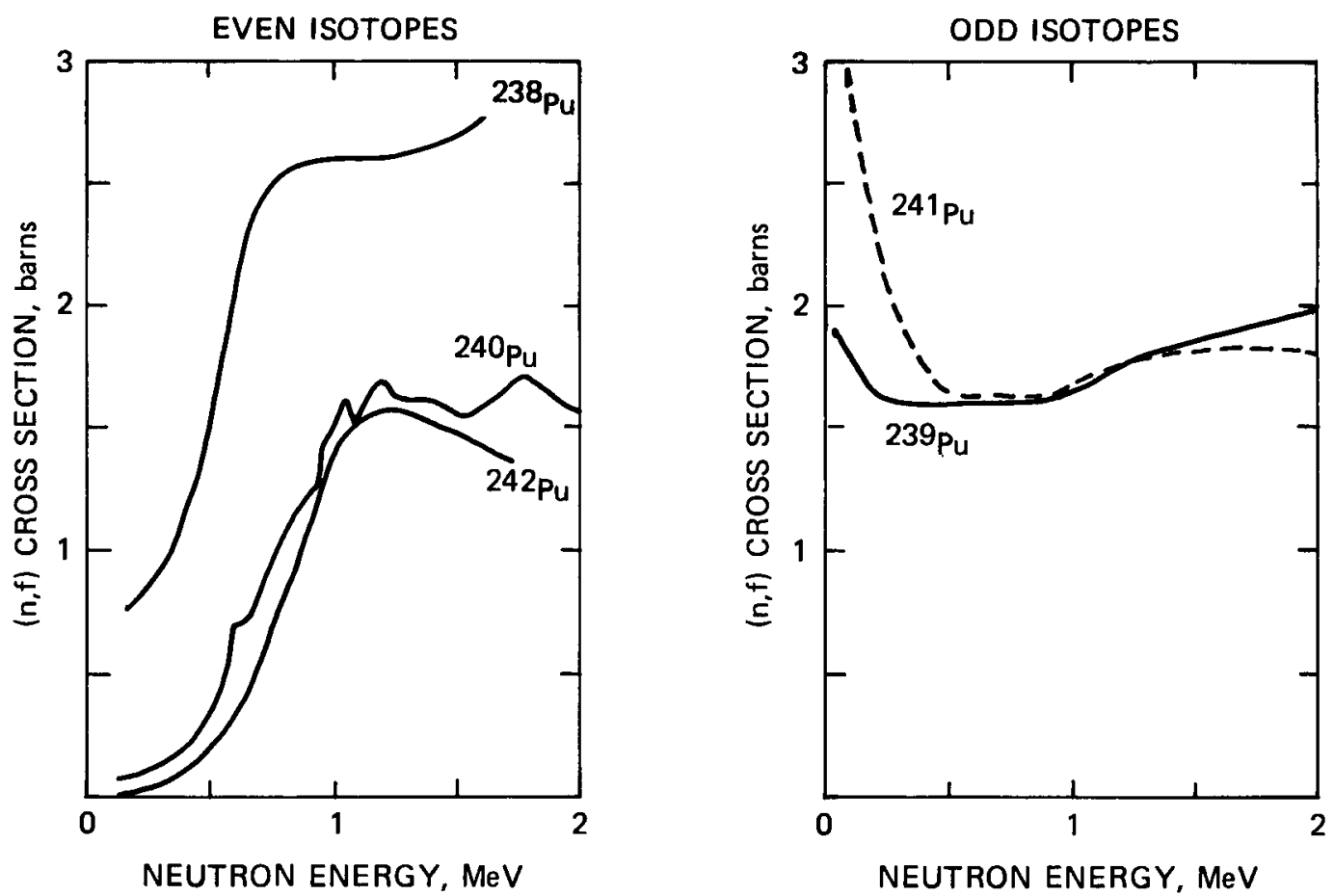

FIGURE 7 - Cross sections for $\mathrm{Pu}(\mathrm{n}, \mathrm{f})$ reactions for several plutonium isotopes. 
TABLE 7 - (n,f) CROSS SECTIONS AT $0.025 \mathrm{eV}$

\begin{tabular}{lc} 
Isotope & $\begin{array}{c}\text { Cross Section } \\
\text { (barns) }\end{array}$ \\
\cline { 3 - 3 }${ }^{238} \mathrm{Pu}$ & 17. \\
${ }^{239} \mathrm{Pu}$ & 742. \\
${ }^{240} \mathrm{Pu}$ & 0.08 \\
${ }^{241} \mathrm{Pu}$ & 1010. \\
${ }^{242} \mathrm{Pu}$ & $<0.2$ \\
${ }^{241} \mathrm{Am}$ & 3.2
\end{tabular}

A property of a neutron emitting sample is its neutron energy spectrum. Unfortunately, measuring a neutron spectrum is a time consuming process. A measure of the average energy of a spectrum can be obtained rather quickly, however, from the ratio of responses for a thermal neutron detector employing two different degrees of moderation; e.g., the front to back ratio for a SNAP detector. Average energies for several different neutron spectra are shown in Table 8. Except where noted, these are for small samples. The average energies will be somewhat different for large samples. 


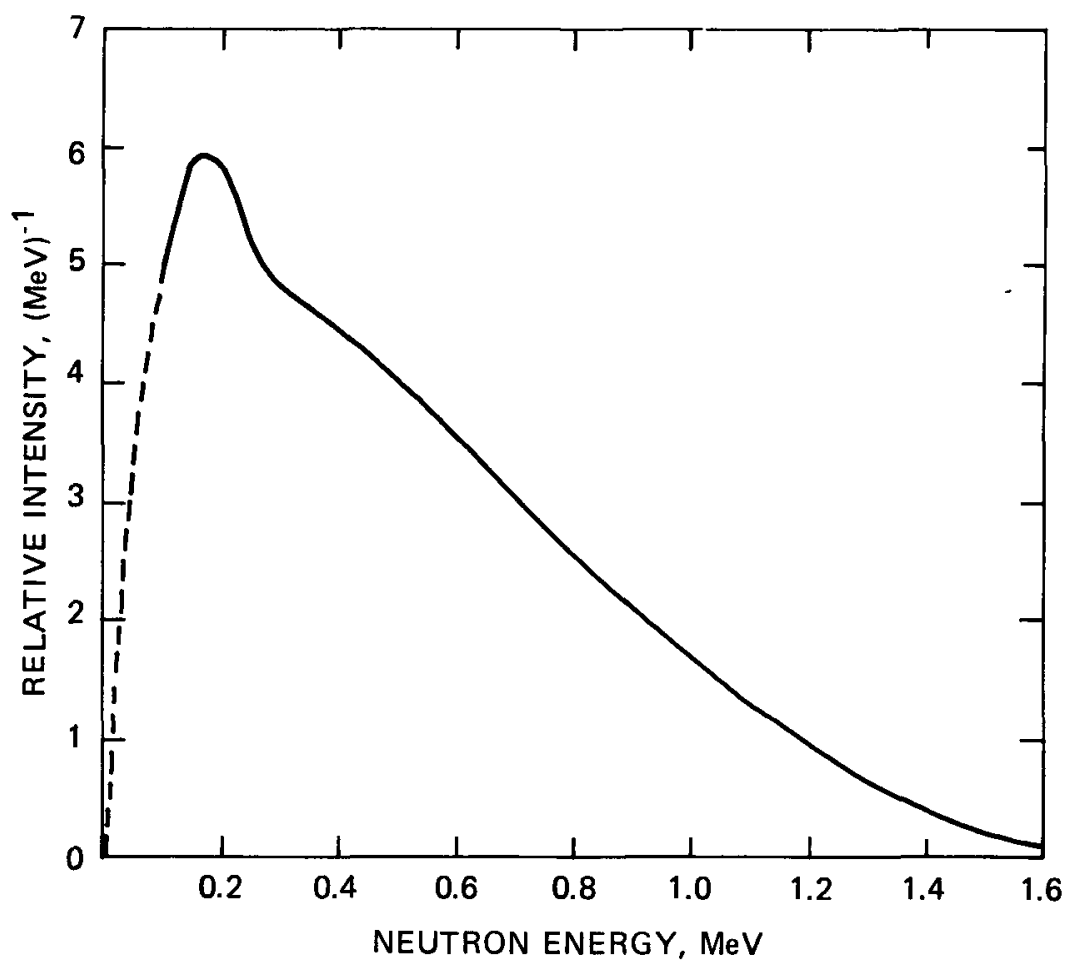

FIGURE 8 - Neutron energy spectrum of a ${ }^{238} \mathrm{Pu}-\mathrm{Li}(\alpha, \mathrm{n})$ source. The dashed curve is a calculation of the $<0.1 \mathrm{MeV}$ portion of the spectrum. 
TABLE 8 - AVERAGE ENERGIES FOR NEUTRON ENERGY SPECTRA

\begin{tabular}{|c|c|}
\hline Source & $\begin{array}{c}\text { Average } \\
\text { Energy } \\
\text { (MeV) } \\
\end{array}$ \\
\hline${ }^{240} \mathrm{Pu}$ (spontaneous fission) & 1.8 \\
\hline${ }^{252} \mathrm{Cf}$ (spontaneous fission) & 2.1 \\
\hline${ }^{238} \mathrm{Pu}-\mathrm{Li}$ & 0.5 \\
\hline${ }^{239} \mathrm{Pu}-\mathrm{F}$ & 1.4 \\
\hline${ }^{238} \mathrm{Pu}-\mathrm{O}$ & $2.0^{\mathrm{a}}$ \\
\hline${ }^{239} \mathrm{Pu}-\mathrm{Be}(80 \mathrm{~g} \mathrm{Pu})$ & 3.9 \\
\hline${ }^{239} \mathrm{Pu}-\mathrm{Be}(13 \mathrm{~g} \mathrm{Pu})$ & 4.5 \\
\hline
\end{tabular}

aff the $\alpha$-emitter were ${ }^{239} \mathrm{Pu}$, the average energy would be a little less. 


\subsubsection{Gamma-ray Properties}

A high-resolution gamma-ray spectrum can provide the most straightforward evidence from a NDA measurement that plutonium is present in a sample. All of the plutonium isotopes with the exception of ${ }^{242} \mathrm{Pu}$ will contribute to such a spectrum. However, for many samples a spectrum cannot be used for quantitative assay unless sample homogeneity has otherwise been ensured. This is because plutonium gamma-ray attenuation coefficients are quite large, especially for energies less than a few hundred $\mathrm{keV}$. Therefore, in cases where sample attenuation is severe, the gamma rays actually measured for a spectrum will primarily be those originating near the surface of the sample.

Figures 9 and 10 are plots of plutonium spectra obtained with a $2 \mathrm{cc}$ intrinsic $\mathrm{Ge}$ detector and a $70 \mathrm{cc} \mathrm{Ge}(\mathrm{Li})$ detector, respectively. Some of the major peaks have been identified with their parent isotopes. The energies of the gamma rays and the general shape of the spectrum can give a qualitative indication of the presence of plutonium. Table 9 lists some of the major gamma rays from plutonium isotopes and ${ }^{241} \mathrm{Am}$ and their intensities per gram of isotope.

An additional degree of assurance that the peaks are only from plutonium can be obtained by comparing different peaks of the same isotope. Detection efficiency, sample self-absorption and the ability to resolve multiplets affect the observed intensities. Therefore, unless all of these factors are taken into account, the ratios derived from spectral data may only approximate the calculated ratios. The effects of detection efficiency and sample self-absorption will tend to cancel for peaks chosen close together in energy. Table 10 lists intensity ratios for four selected gamma rays from ${ }^{239} \mathrm{Pu}$.

If the peak areas of gamma rays from different isotopes are known, the plutonium isotopic composition of a sample can be approximated. To minimize the effects of sample self-absorption and detector efficiency, gamma rays are usually chosen close together in energy. The changes in spectral shape resulting from changes in plutonium isotopic composition are illustrated in Figure 11. These spectra show how the $153 \mathrm{keV}$ gamma ray from ${ }^{238} \mathrm{Pu}$ increases in intensity with increasing burnup. (The $170 \mathrm{keV}$ peak from ${ }^{241} \mathrm{Am}$ is not an indicator of burnup, but simply was present in various amounts in these spectra.) Table 11 is a summary of some peak area ratios from the isotopic compositions given in Table 2. 


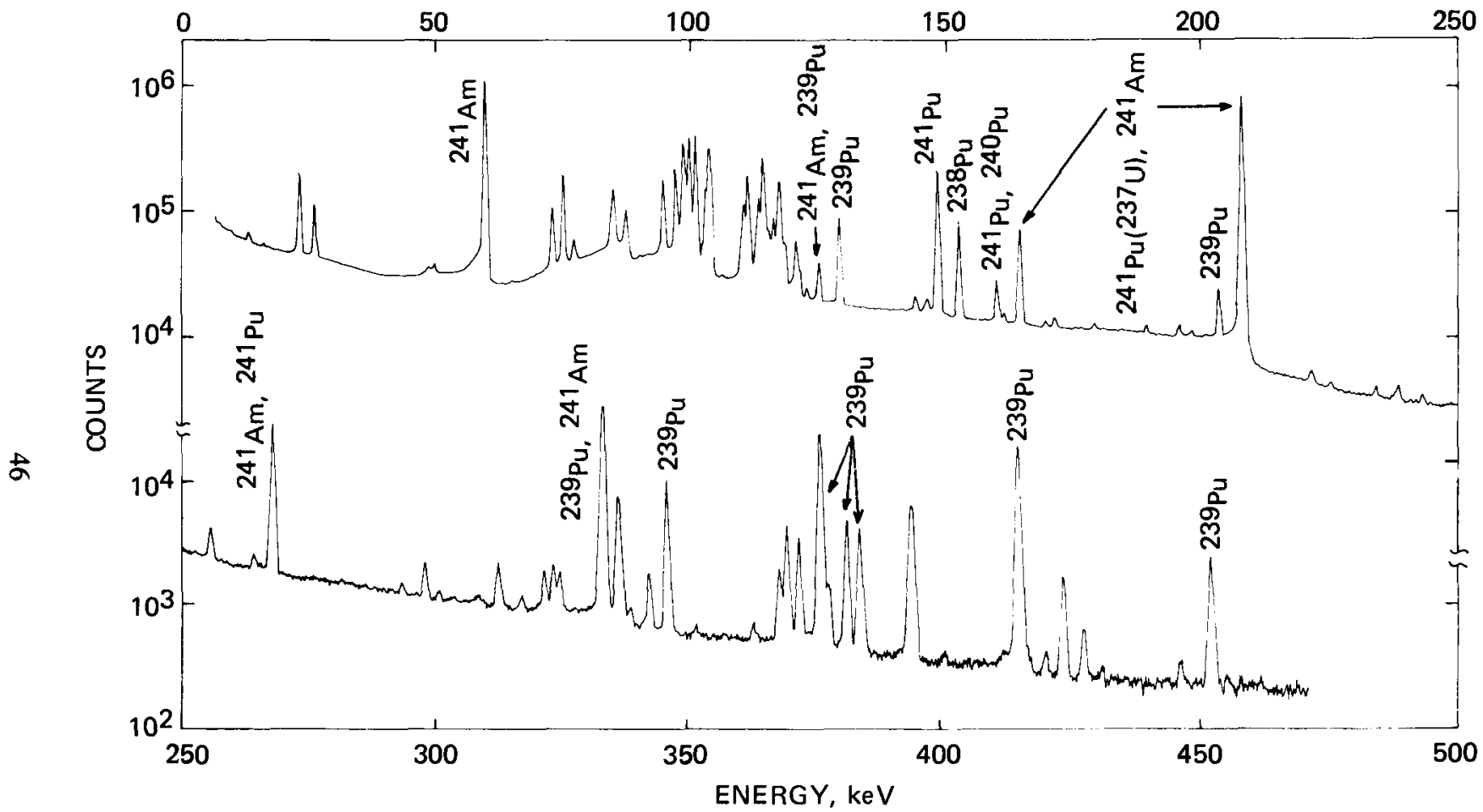

FIGURE 9 - Plutonium spectrum obtained with a $2 \mathrm{cc}$ intrinsic Ge detector. The mass ratios in weight percent for this sample are: ${ }^{238} \mathrm{Pu} 1.1,{ }^{239} \mathrm{Pu} 70.8,{ }^{240} \mathrm{Pu} 24.1,{ }^{241} \mathrm{Pu} 2.7,{ }^{242} \mathrm{Pu} \mathrm{1.2}$, and ${ }^{241} \mathrm{Am} \mathrm{0.6.}$ 


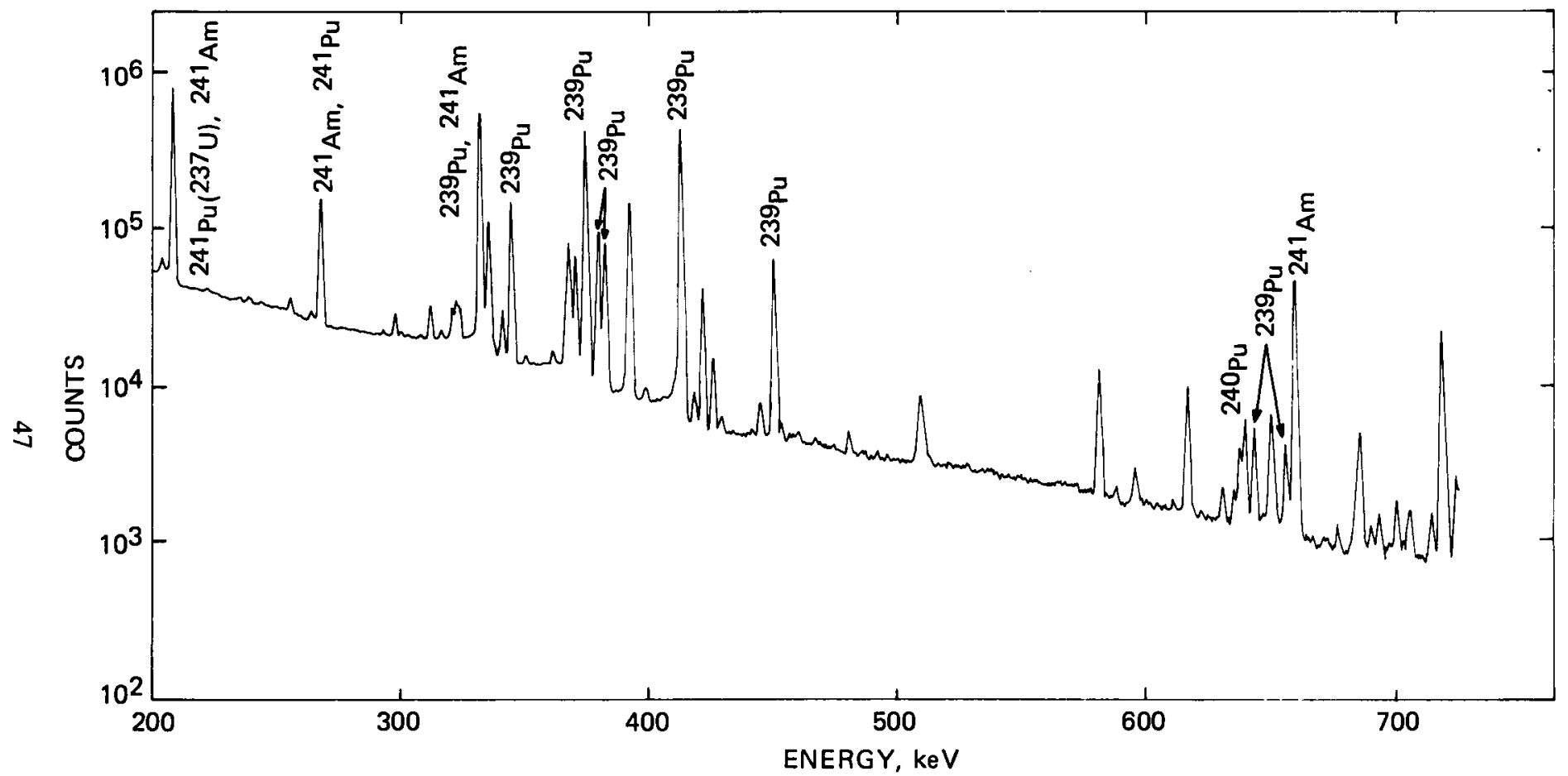

FIGURE 10 - Plutonium spectrum obtained with a $70 \mathrm{cc} \mathrm{Ge}(\mathrm{Li})$ detector. The mass ratios in weight percent for this sample are: ${ }^{238} \mathrm{Pu} 1.1,{ }^{239} \mathrm{Pu} 70.8,{ }^{240} \mathrm{Pu} 24.1,{ }^{241} \mathrm{Pu} 2.7,{ }^{242} \mathrm{Pu} 1.2$, and ${ }^{241} \mathrm{Am} \mathrm{0.6}$. 
TABLE 9 - PRINCIPAL GAMMA RAYS FOR PLUTONIUM AND AMERICIUM-24I

\begin{tabular}{|c|c|c|}
\hline Isotope & $\begin{array}{c}\text { Energy } \\
(\mathrm{keV})\end{array}$ & $\begin{array}{c}\text { Intensity } \\
(\gamma / \mathrm{sec}-\mathrm{g} \text { of isotope })\end{array}$ \\
\hline${ }^{238} \mathrm{Pu}$ & 152.7 & $6.1 \times 10^{6}$ \\
\hline \multirow[t]{11}{*}{${ }^{239} \mathrm{Pu}$} & 129.3 & $1.4 \times 10^{5}$ \\
\hline & 203.5 & $1.3 \times 10^{4}$ \\
\hline & 332.8 & $1.1 \times 10^{4}$ \\
\hline & 345.0 & $1.3 \times 10^{4}$ \\
\hline & 375.0 & $3.6 \times 10^{4}$ \\
\hline & 380.2 & $7.0 \times 10^{3}$ \\
\hline & 382.8 & $5.9 \times 10^{3}$ \\
\hline & 413.7 & $3.5 \times 10^{4}$ \\
\hline & 451.5 & $4.3 \times 10^{3}$ \\
\hline & 640.1 & $1.8 \times 10^{2}$ \\
\hline & 645.0 & $3.3 \times 10^{2}$ \\
\hline \multirow[t]{2}{*}{${ }^{240} \mathrm{Pu}$} & 160.3 & $3.4 \times 10^{4}$ \\
\hline & 642.5 & $1.1 \times 11^{3}$ \\
\hline \multirow[t]{5}{*}{${ }^{24} \mathrm{Pu}$} & 148.6 & $7.1 \times 10^{6}$ \\
\hline & 160.0 & $2.6 \times 10^{5}$ \\
\hline & 164.6 & $1.7 \times 10^{6}$ \\
\hline & 208.0 & $2.0 \times 10^{7}$ \\
\hline & 267.5 & $6.8 \times 10^{5}$ \\
\hline \multirow[t]{14}{*}{${ }^{241} \mathrm{Am}$} & 59.6 & $4.5 \times 10^{10}$ \\
\hline & 125.3 & $5.2 \times 10^{6}$ \\
\hline & 146.6 & $5.8 \times 10^{5}$ \\
\hline & 169.6 & $2.2 \times 10^{5}$ \\
\hline & 208.0 & $1.0 \times 10^{6}$ \\
\hline & 267.5 & $3.3 \times 10^{4}$ \\
\hline & 322.5 & $1.9 \times 10^{5}$ \\
\hline & 332.3 & $1.9 \times 10^{5}$ \\
\hline & 335.4 & $6.3 \times 10^{5}$ \\
\hline & 368.6 & $2.7 \times 10^{5}$ \\
\hline & 376.6 & $1.7 \times 10^{5}$ \\
\hline & 419.2 & $3.6 \times 10^{4}$ \\
\hline & 619.0 & $7.5 \times 10^{4}$ \\
\hline & 662.4 & $4.6 \times 10^{5}$ \\
\hline
\end{tabular}




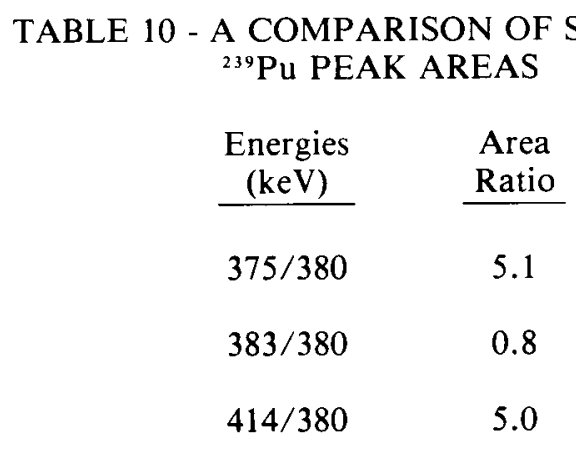

TABLE 11 - SELECTED RATIOS OF PLUTONIUM PEAK AREAS FOR DIFFERENT BURNUPS USING THE GAMMA-

RAY ENERGIES (IN keV) SHOWN IN PARENTHESESa

\begin{tabular}{|c|c|c|c|}
\hline $\begin{array}{c}\text { Burnup } \\
(1000 \mathrm{MWD} / \mathrm{t})\end{array}$ & $\begin{array}{c}{ }^{28} \mathrm{Pu} /{ }^{2+1} \mathrm{Pu} \\
(153 / 148)\end{array}$ & $\begin{array}{c}{ }^{238} \mathrm{Pu} /{ }^{239} \mathrm{Pu} \\
(153 / 144)\end{array}$ & $\begin{array}{c}{ }^{24} \mathrm{Pu} /{ }^{234} \mathrm{Pu} \\
(148 / 144)\end{array}$ \\
\hline Low & 0.02 & 0.1 & 6. \\
\hline $8-10$ & 0.04 & 1.1 & 30. \\
\hline $16-18$ & 0.05 & 3.1 & 66. \\
\hline $25-27$ & 0.09 & 16.0 & 171. \\
\hline $38-40$ & 0.11 & 41.4 & 366. \\
\hline
\end{tabular}

aSome of the peaks in this table may not be usable if counting statistics are poor. 


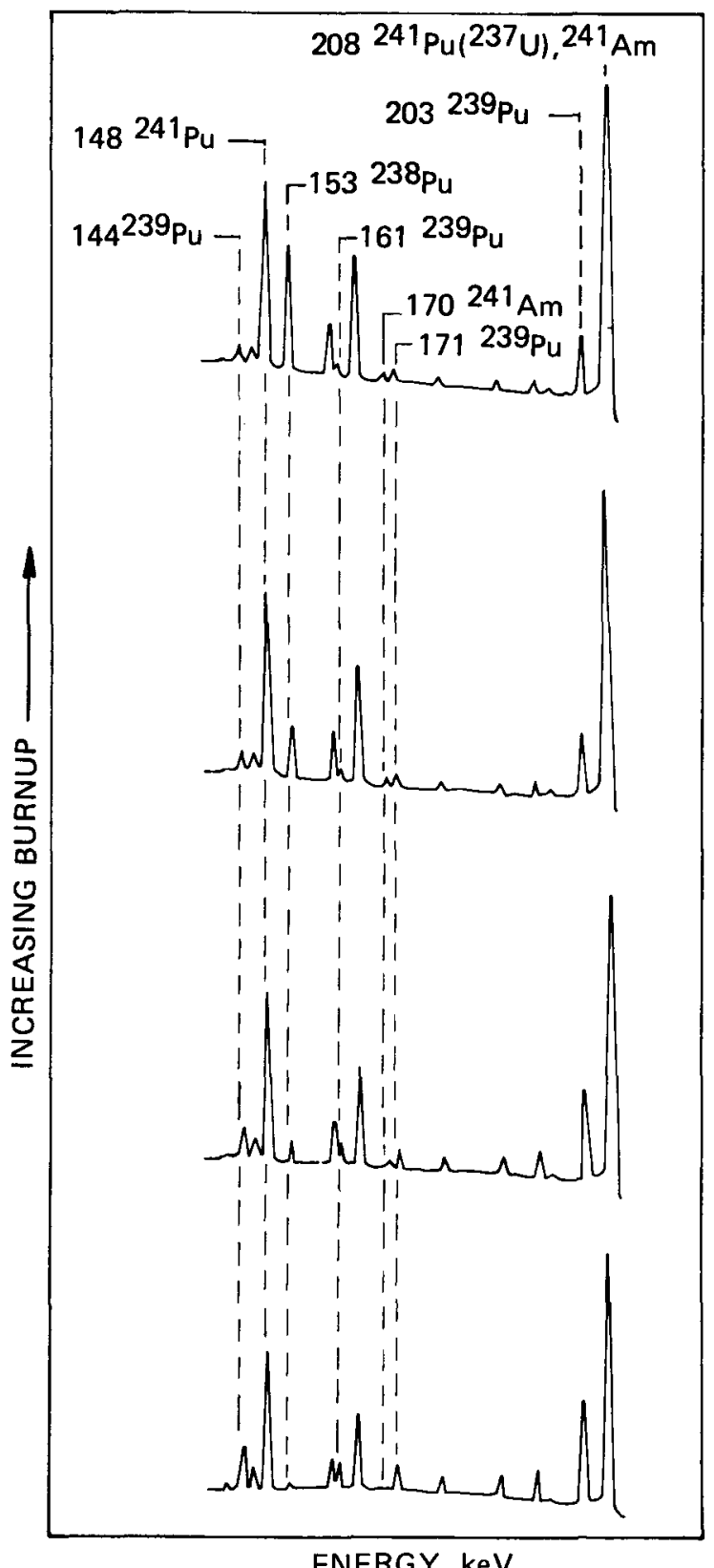

FIGURE 11 - Effect of increasing burnup on a plutonium spectrum in the energy region $144-208 \mathrm{keV}$. 
Gamnia-rat atlenuation by a sample can be used w dedtece cerlain sample properties. The fraction of gamma rays transmilled through a homogeneous material of uniform thickness is given by:

$$
\frac{1}{I_{1}}=\mathrm{e}^{-\mu e x}
$$

where $\mathrm{I}_{0} \equiv$ incident gamma-ray intensity,

$\mu \equiv$ mass attenuation coefficient $\left(\mathrm{cm}^{2} / \mathrm{g}\right)$,

$\varrho \equiv$ bulk density $\left(\mathrm{g} / \mathrm{cm}^{3}\right)$, and

$\mathrm{x} \equiv$ thickness $(\mathrm{cm})$.

Figure 12 shows mass attenuation curves for aluminum, iron, and plutonium. Note the K-absorption edge for plutonium at $121.8 \mathrm{keV}$. With a high resolution transmission measurement, this edge can be used to identify plutonium. For comparison, the uranium $\mathrm{K}$-absorption edge is at $115.6 \mathrm{keV}$.

If there are $m$ materials between the gamma-ray transmission source and detector, the fraction transmitted is given by:

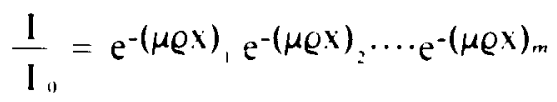

When an absorbing material is composed of $n$ elements, the effective mass attenuation coefficient $\mu$ for that material is given by:

$$
\mu=\sum_{j}^{n} w, \mu,
$$

where $w_{i} \equiv$ bulk sample weight fraction for element $\mathrm{j}$, and $\mu_{i} \equiv$ mass attenuation coefficient for element $\mathrm{j}$.

Table 12 lists effective mass attenuation coefficients for selected elements and compounds. The $375 \mathrm{keV}$ complex and the $414 \mathrm{keV}$ gamma ray are often used in plutonium assay.

The thickness for $50 \%$ attenuation is sometimes called a "half-value layer." The transmission ratio $\mathbf{I} / \mathbf{I}_{0}$ is related to the number of halfvalue layers $\mathrm{n}$ by:

$$
\frac{I}{I_{10}}=(1 / 2)^{n}
$$




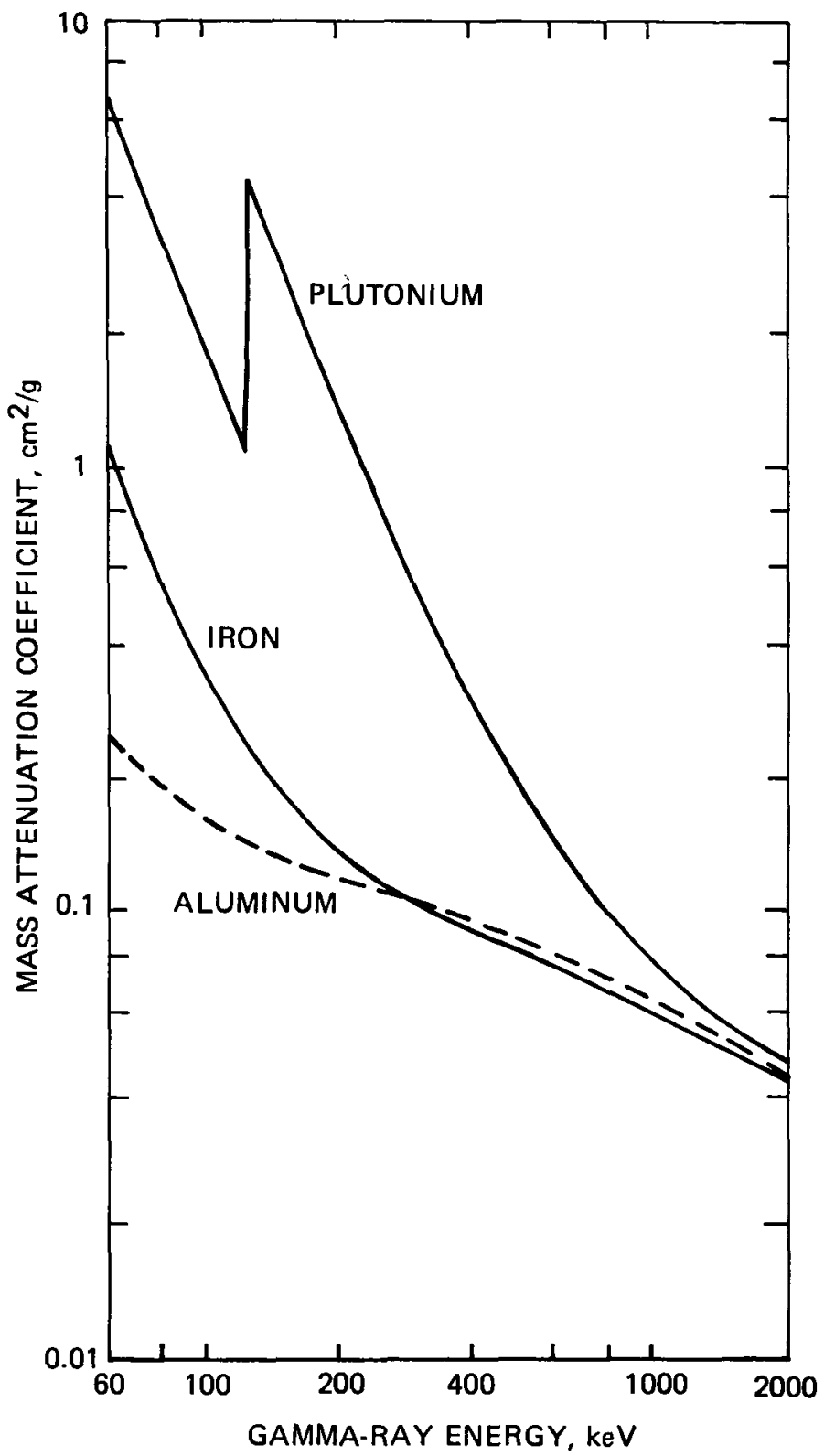

FIGURE 12 - Mass attenuation coefficients for aluminum, iron, and plutonium. (The curve for aluminum is drawn with dashes to differentiate it from that for iron.) 


\section{TABLE 12 - EFFECTIVE MASS ATTENUATION COEFFICIENTS FOR SELECTED MATERIALS}

\begin{tabular}{|c|c|c|c|}
\hline & $\begin{array}{c}\mathrm{E}_{\gamma}=129 \mathrm{keV} \\
\left(\mathrm{cm}^{2} / \mathrm{g}\right)\end{array}$ & $\begin{array}{c}\mathrm{E}_{\gamma}=375 \mathrm{keV} \\
\left(\mathrm{cm}^{2} / \mathrm{g}\right)\end{array}$ & $\begin{array}{c}\mathrm{E}_{\gamma}=414 \mathrm{keV} \\
\left(\mathrm{cm}^{2} / \mathrm{g}\right)\end{array}$ \\
\hline $\begin{array}{l}\text { Pu } \\
\text { Metal }\end{array}$ & 3.9 & 0.32 & 0.27 \\
\hline $\mathrm{PuO}_{2}$ & 3.4 & 0.29 & 0.25 \\
\hline $\mathrm{PuF}_{4}$ & 3.0 & 0.27 & 0.23 \\
\hline $\mathrm{Fe}$ & 0.22 & 0.094 & 0.090 \\
\hline $\mathrm{Al}$ & 0.14 & 0.095 & 0.091 \\
\hline
\end{tabular}

The density used in a transmission calculation is bulk density, which is a function of particle size and packaging. For example, while the theoretical density of $\mathrm{PuO}_{2}$ is $11.5 \mathrm{~g} / \mathrm{cm}^{3}$, the density of poured $\mathrm{PuO}_{2}$ powder is only $\sim 3 \mathrm{~g} / \mathrm{cm}^{3}$.

Figures 13 and 14 show gamma-ray transmission, $\left(\mathrm{I} / \mathrm{I}_{0}\right) \times 100 \%$, as a function of gamma-ray energy for iron and plutonium. Each figure shows plots for different values of density thickness, ex. The right hand ordinate scale is the fractional transmission, which is the factor $e^{-\mu Q x \text {. }}$

For solution samples in which homogeneity can be ensured by mixing, comparison between two gamma rays having significantly different energies can yield the density of plutonium in the solution, provided the sample is not infinitely thick to both gamma rays. This measurement has been done for plutonium solutions using the 129 and $414 \mathrm{keV}$ gamma rays from ${ }^{239} \mathrm{Pu}$ as described in Reference 1.

If a valid calibration curve is available, either the quantity of a particular plutonium isotope or its weight fraction in a sample can be obtained from counting data. In the absence of such a curve, it may be possible to obtain an estimate of the weight fraction for a homogeneous sample of uniform thickness from: 


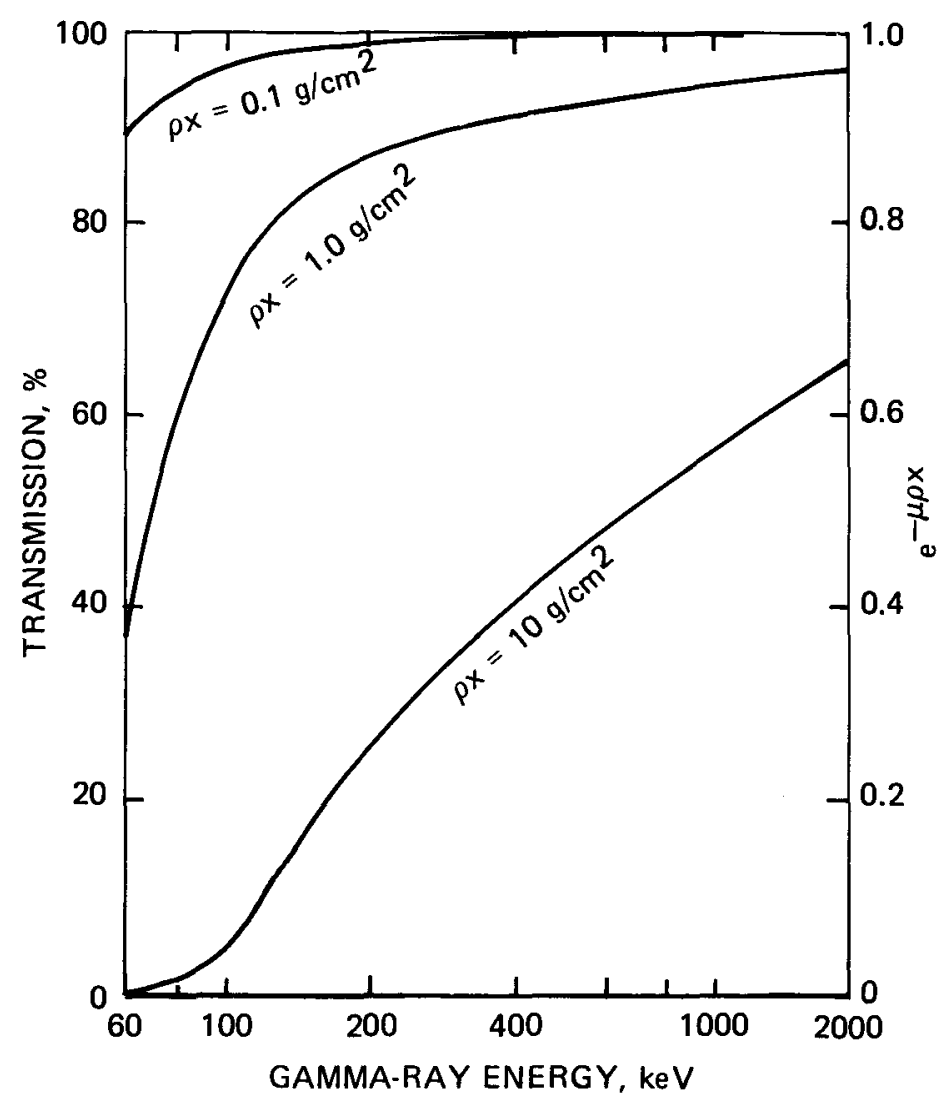

FIGURE 13 - Gamma-ray transmission of iron for three thicknesses. 


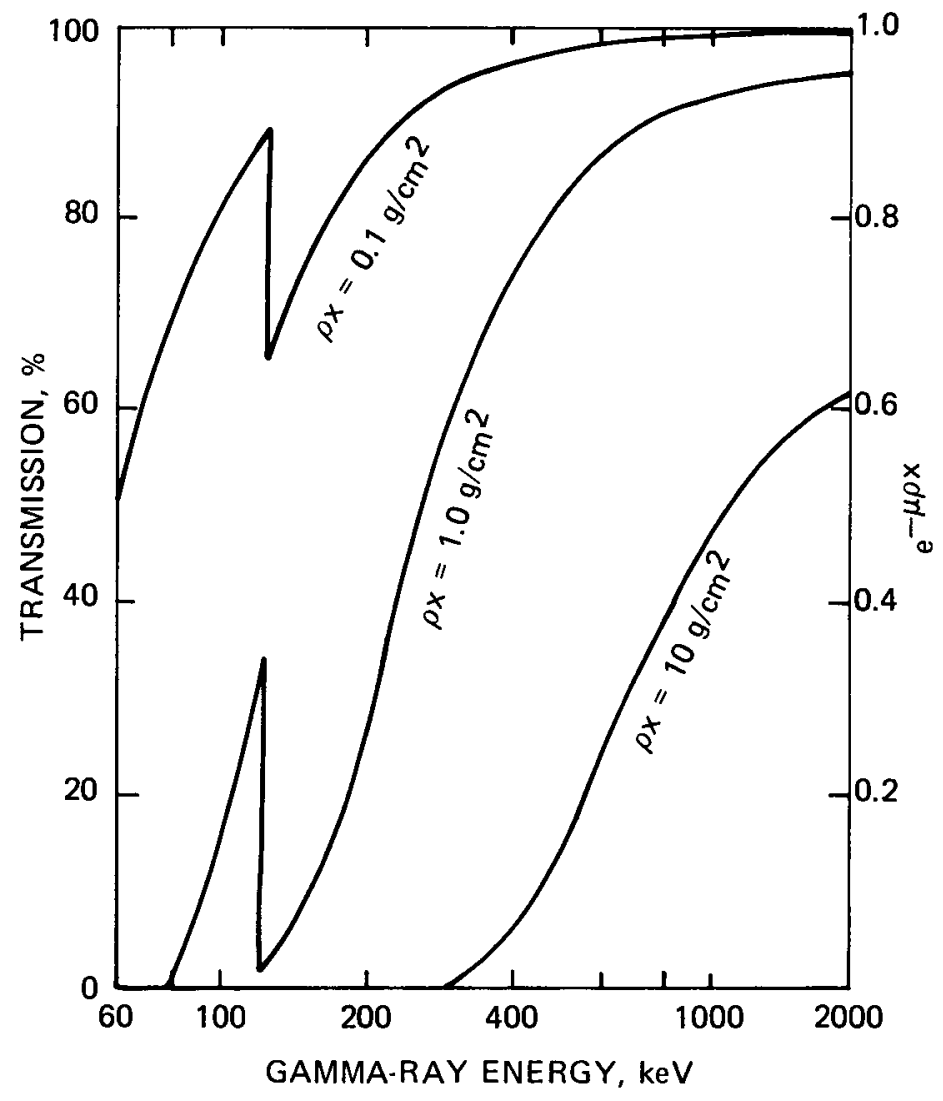

FIGURE 14 - Gamma-ray transmission of plutonium for three thicknesses. 


$$
C=\frac{F G A \varepsilon}{\mu_{p_{u}}}\left(\frac{1}{1+\frac{\mu_{m} Q_{m}}{\mu_{P_{u}} Q_{P_{u}}}}\right) S T
$$

where $\mathrm{C} \equiv$ photopeak counting rate

$\mathrm{F} \equiv$ weight fraction of the plutonium isotope to total plutonium

$\mathrm{G} \equiv$ gamma-ray emission rate per gram of plutonium

A $\equiv$ area of sample viewed by detector

$\varepsilon \equiv$ detector photopeak efficiency (including sourcedetector geometry factor)

$\mu_{P_{u}} \equiv$ mass attenuation coefficient for plutonium

$\mu_{m} \equiv$ mass attenuation coefficient for non-plutonium portions of the sample

$Q_{P_{u}} \equiv$ bulk density for plutonium

$\varrho_{m} \equiv$ bulk density for non-plutonium portion of the sample

$\mathrm{S} \equiv$ source term (defined below)

$\mathrm{T} \equiv$ container transmission term (see below).

The source term $\mathrm{S}$ in Equation 9 accounts for sample thickness and is given by:

$$
\mathrm{S}=1-\mathrm{e}^{-\mu \rho x}
$$

where $\mu$ is the sample mass attenuation coefficient (from Equation 7), $\varrho$ is the sample bulk density, and $x$ is the sample thickness. As $x$ increases, the exponential term decreases. A sample is said to be "infinitely thick" when $x$ is large enough that the exponential term has a value of almost zero. Table 13 presents values for $x$ when the exponential term equals 0.01 (i.e., $S=0.99$ ). 
The container transmission term, T, in Equation 9 accounts for gamma-ray attenuation by the container. For a container whose thickness is uniform for the gamma rays being counted, this term is given by Equation 6 . During a measurement, a collimator can be used to ensure that the portion of the sample viewed is of uniform thickness.

Note that Equation 9 reduces to the enrichment equation when $\mathrm{S}$ is equal to 1 .

\section{TABLE 13 - “INFINITE THICKNESS” VALUES FOR DIFFERENT SAMPLES}

\begin{tabular}{|c|c|c|c|}
\hline \multirow[b]{2}{*}{ Sample } & \multirow{2}{*}{$\begin{array}{c}\text { Bulk } \\
\text { Density } \\
\left(\mathrm{g} / \mathrm{cm}^{3}\right)\end{array}$} & \multicolumn{2}{|c|}{ Thickness $(\mathrm{cm})$ for $\mathrm{S}=0.99$} \\
\hline & & $E_{\gamma}=129 \mathrm{keV}$ & $E_{\gamma}=375 \mathrm{keV}$ \\
\hline Pu Metal & 19.60 & 0.06 & 0.7 \\
\hline $\mathrm{PuO}_{2}$ & 11.46 & 0.12 & 1.4 \\
\hline $\mathrm{PuO}_{2}$ & 3.00 & 0.45 & 5.2 \\
\hline
\end{tabular}




\subsubsection{Thermal Properties}

The thermal power of plutonium is primarily a result of $\alpha$-decay. Table 14 is a list of specific powers for various isotopes.

\section{TABLE 14 - SPECIFIC POWERS FOR PLLITONIUM AND OTHER ISOTOPES}

\begin{tabular}{|c|c|c|c|}
\hline Isotope & $\begin{array}{c}\text { Specific Power } \\
\text { (mW/g of isotope) }\end{array}$ & Isotope & $\begin{array}{c}\text { Specific Power } \\
(\mathrm{mW} / \mathrm{g} \text { of isotope })\end{array}$ \\
\hline${ }^{278} \mathrm{Pu}$ & $5.67 \times 10^{2}$ & ${ }^{2+2} \mathrm{Pu}$ & $1.15 \times 10^{-1}$ \\
\hline${ }^{2{ }^{29}} \mathrm{Pu}$ & 1.93 & $\therefore 1 \mathrm{Am}$ & $1.14 \times 10^{2}$ \\
\hline${ }^{20} \mathrm{Pu}$ & 7.10 & $\therefore \mathrm{Cm}$ & $1.22 \times 10^{5}$ \\
\hline${ }^{2} \mathrm{Pu}$ & 3.39 & ${ }^{2\lrcorner+} \mathrm{Cm}$ & $2.83 \times 10^{3}$ \\
\hline
\end{tabular}

The total specific power $P_{\text {eff }}$ can be calculated from:

$$
P_{\text {eft }}=\sum w_{i} P_{\text {. }}
$$

where $w$ is the isotope weight fraction, $P$ is the specific power, and $i$ refers to each plutonium isotope and ${ }^{241} \mathrm{Am}$.

Figure 15 illustrates the change in specific power as the plutonium composition changes. Note, for instance, that in a low burnup sample ${ }^{239} \mathrm{Pu}$ contributes $78 \%$ of the total power $\left(\mathrm{P}_{\text {eff }}=2.29 \mathrm{~mW} / \mathrm{g}\right)$ while in the $38-40 \mathrm{MWD} / \mathrm{t}$ case ${ }^{239} \mathrm{Pu}$ contributes only $6 \%$ of the total power $\left(\mathrm{P}_{\text {eff }}=14.65 \mathrm{~mW} / \mathrm{g}\right)$. The equation for specific power as a function of time due to ${ }^{241} \mathrm{Am}$ ingrowth is given by:

$$
\mathrm{P}_{\text {off }}(\mathrm{t})=\sum_{\mathrm{i}=1}^{5} \mathrm{w}_{i} \mathrm{P}_{i} \mathrm{e}^{-\lambda_{i} \mathrm{t}}+\mathrm{w}_{4} \mathrm{P}_{6} \frac{\lambda_{4}}{\lambda_{4}-\lambda_{6}}\left(\mathrm{e}^{-\lambda_{6} \mathrm{t}}-\mathrm{e}^{-\lambda_{4} \mathrm{t}}\right)
$$

where subscripts 1-6 refer to ${ }^{238} \mathrm{Pu},{ }^{239} \mathrm{Pu},{ }^{240} \mathrm{Pu},{ }^{241} \mathrm{Pu},{ }^{242} \mathrm{Pu}$, and ${ }^{2+1}$ Am respectively; $\lambda=\ln 2 / \mathrm{T}_{1 / 2}$, where $\mathrm{T}_{1 / 2}$ is the half-life; and $t=$ 0 , when the ${ }^{2+1} \mathrm{Am}$ content is zero. The change in power with time due to the ingrowth of ${ }^{241} \mathrm{Am}$ is illustrated in Figure 16. (Note that Equation 12, specific power as a function of time, is the same form as Equation 4, neutron yield as a function of time.) 


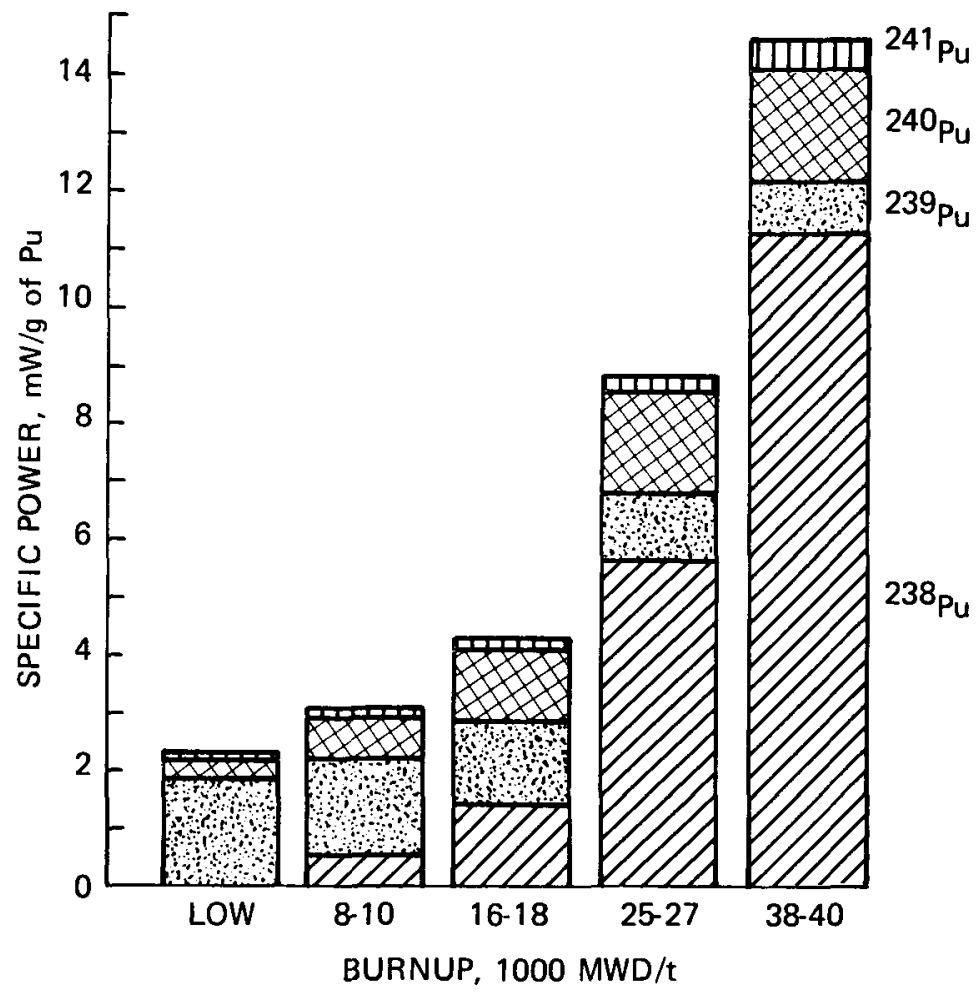

FIGURE 15 - Specific powers for the different plutonium compositions given in Table 2 . 


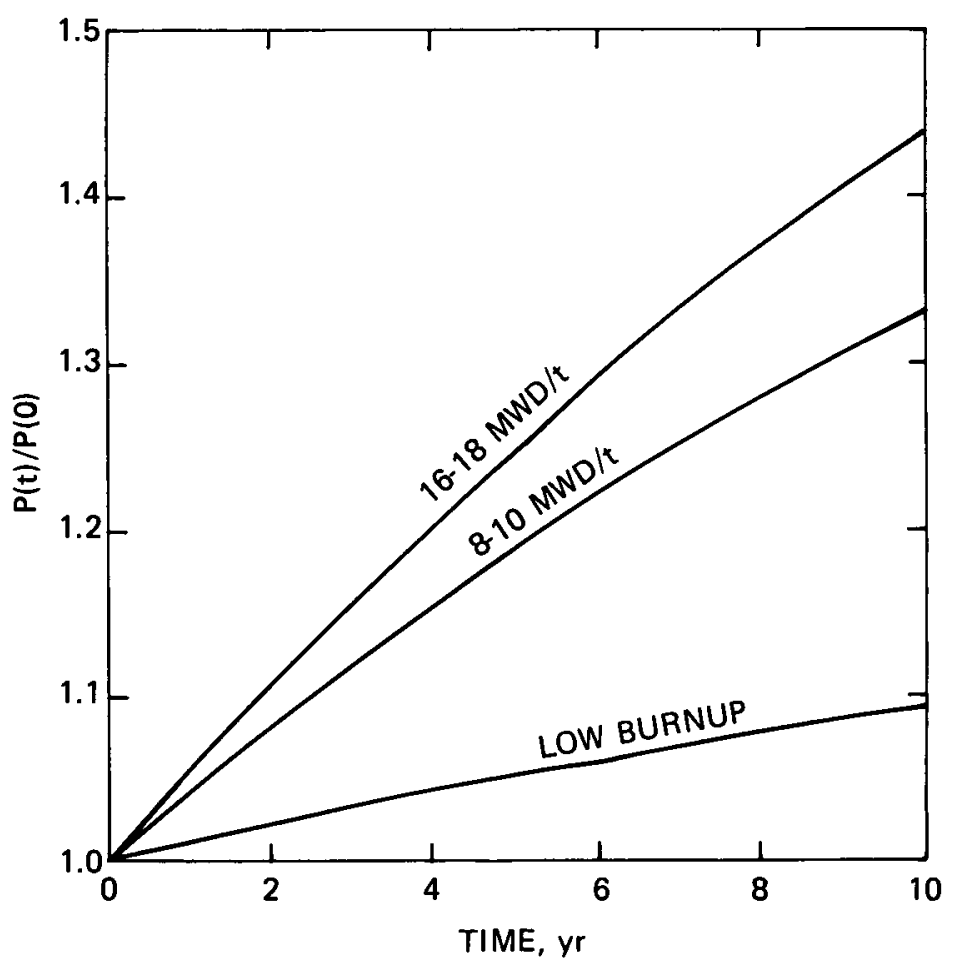

FIGURE 16 - The thermal power at time $t$ relative to that at separation (time 0$), P(t) / P(0)$, for various burnups. The curves for $25-27$ and $38-40 \mathrm{MWD} / \mathrm{t}$ burnups would lie very close to that for $16-18$ MWD/t burnup. 


\subsection{Uranium}

Quantitative assay of uranium is dependent on its isotopic composition. Naturally occurring uranium has the isotopic composition shown in Table 15.

\section{TABLE 15 - ISOTOPIC ABUNDANCES FOR NATURALLY OCCURRING URANIUM}

$\begin{array}{ll}\frac{\text { Isotope }}{{ }^{234} \mathrm{U}} & \text { wt \%0 } \\ { }^{235} \mathrm{U} & 0.0054 \\ { }^{236} \mathrm{U} & 0.720\end{array}$

The ${ }^{23} \mathrm{U} /{ }^{235} \mathrm{U}$ ratio for natural uranium is 0.0075 . This ratio may be different for uranium that has been enriched or depleted in ${ }^{235} \mathrm{U}$.

If a sample contains uranium that has been irradiated in a reactor, additional uranium isotopes will be present with the most abundant being ${ }^{236} \mathrm{U}$. (In some material in the USA the ${ }^{236} \mathrm{U} / \mathrm{U}$ ratio was $\sim 0.3$ in 1981 , and it is expected to rise to $\sim 0.4$ by 1990 , as stated in Reference 2.)

Table 16 lists half-lives for several uranium isotopes.

\section{TABLE 16 - HALF-LIVES FOR URANIUM ISOTOPES}

\begin{tabular}{|c|c|c|c|}
\hline Isotope & Half-Life & Isotope & Half-Life \\
\hline${ }^{232} \mathrm{U}$ & $7.0 \times 10^{\prime} \mathrm{yr}$ & ${ }^{236} \mathrm{U}$ & $2.34 \times 10^{7} \mathrm{yr}$ \\
\hline${ }^{233} \mathrm{U}$ & $1.59 \times 10^{5} \mathrm{yr}$ & ${ }^{237} \mathrm{U}$ & $6.75 \mathrm{da}$ \\
\hline${ }^{234} \mathrm{U}$ & $2.46 \times 10^{5} \mathrm{yr}$ & ${ }^{238} \mathrm{U}$ & $4.47 \times 10^{9} \mathrm{yr}$ \\
\hline${ }^{235} \mathrm{U}$ & $7.04 \times 10^{8} \mathrm{yr}$ & & \\
\hline
\end{tabular}




\subsubsection{Neutron Properties}

The spontaneous fission and $(\alpha, \mathrm{n})$ neutron yields for uranium isotopes are given in Table 17. These yields are for nonmultiplying samples containing $1 \mathrm{~g}$ of the isotope. Note that the uranium neutron yields in Table 17 are considerably lower than corresponding plutonium neutron yields given in Table 4 . Also, see Table 4 for the neutron yields of isotopes that, if present, could cause measurement interference.

The thick target yields for uranium isotopes, which were used for calculating the yields shown in Table 17 are given in Table 18. The reduction in yield factor for other than thick targets is given as Equation 1. The stopping power ratios given in Table 6 can be used in Equation 1 for uranium yield calculations as well as for plutonium.

The total yields for $\mathrm{UO}_{2}, \mathrm{UF}_{6}$ and $\mathrm{UAl}_{\mathrm{X}}$ are the sums of the $(\alpha, \mathrm{n})$ yields and the spontaneous fission yields. The data in Table 17 do not include any contributions from daughters. Except for ${ }^{232} \mathrm{U}$, the neutron contributions from daughters are negligible and uranium samples without ${ }^{232} \mathrm{U}$ will have essentially constant neutron emission rates for many years. For ${ }^{232} U$, the $(\alpha, n)$ contributions from daughters are quite significant. In the ${ }^{232} \mathrm{U}$ decay chain, the buildup of daughters is controlled principally by ${ }^{228} \mathrm{Th}$ which has a half-life of 1.91 years. In this decay chain 5 alpha-particles are emitted, and their energies are greater than those from the uranium isotopes shown in Table 18. Higher energies mean higher yields from $(\alpha, n)$ reactions. The net result is that for a sample containing ${ }^{232} \mathrm{U}$, the neutron yields from $(\alpha, \mathrm{n})$ reactions will increase considerably with time. At 10 years, transient equilibrium is almost reached, and at this time the yields for ${ }^{232} \mathrm{U}$ plus daughters, given as $\mathrm{n} / \mathrm{sec}-\mathrm{g}\left({ }^{232} \mathrm{U}\right)$, will be approximately: $\mathrm{UO}_{2}, 1.8 \times 10^{5} ; \mathrm{UF}_{6}, 5.2 \times 10^{7}$; and $\mathrm{UAl}_{\mathrm{X}}, 1.4 \mathrm{x}$ $10^{7}$.

Table 19 illustrates the significance of trace amounts of ${ }^{232} \mathrm{U}$ on neutron yields for uranium samples when $(\alpha, n)$ reactions are present. In that table are listed the ratios of weights between ${ }^{2:} \mathrm{U}$ and each of ${ }^{23} \mathrm{U}$, ${ }^{33} \mathrm{U}$, and ${ }^{238} \mathrm{U}$ at which the neutron yields from ${ }^{232} \mathrm{U}$ are equal to those for the other isotopes. For example, at separation the neutron yield from only $0.82 \mu \mathrm{g}$ of ${ }^{23} \mathrm{U}$ will equal that from $1 \mathrm{~g}$ of ${ }^{238} \mathrm{U}$ in $\mathrm{UO}_{2}$. 
TABLE 17 - NEUTRON YIELDS FOR URANIUM ISOTOPES

\begin{tabular}{|c|c|c|c|c|}
\hline \multirow[b]{3}{*}{ Isotope } & \multicolumn{4}{|c|}{ Yields ( $\mathrm{n} / \mathrm{sec}-\mathrm{g}$ of isotope) } \\
\hline & \multirow[b]{2}{*}{$\begin{array}{c}\text { Spontaneous } \\
\text { Fission } \\
\end{array}$} & \multicolumn{3}{|c|}{$(\alpha, \mathrm{n})$ Reactions } \\
\hline & & $\mathrm{UO}_{2}$ & $\mathrm{UF}_{6}$ & $\begin{array}{c}\text { Aluminum } \\
(20 \mathrm{wt} \% \mathrm{U})\end{array}$ \\
\hline${ }^{232} \mathrm{U}$ & 1.7 & $1.7 \times 10^{4}$ & $3.6 \times 10^{6}$ & $3.8 \times 10^{5}$ \\
\hline${ }^{233} \mathrm{U}$ & $<4 . \times 10^{-4}$ & 4.7 & $7.9 \times 10^{2}$ & $5.3 \times 10^{\prime}$ \\
\hline${ }^{234} \mathrm{U}$ & $7.6 \times 10^{-3}$ & 3.0 & $5.1 \times 10^{2}$ & $3.4 \times 10^{1}$ \\
\hline${ }^{235} \mathrm{U}$ & $1.1 \times 10^{-5}$ & $7.2 \times 10^{-4}$ & $1.0 \times 10^{-1}$ & $5.2 \times 10^{-3}$ \\
\hline${ }^{236} \mathrm{U}$ & $4.4 \times 10^{-3}$ & $2.4 \times 10^{-2}$ & 3.3 & $2.0 \times 10^{-1}$ \\
\hline${ }^{238} \mathrm{U}$ & $1.4 \times 10^{-2}$ & $8.5 \times 10^{-5}$ & $1.1 \times 10^{-2}$ & $4.6 \times 10^{-4}$ \\
\hline
\end{tabular}

TABLE 18 - THICK TARGET $(\alpha, n)$ NEUTRON YIELDS FOR URANIUM ISOTOPES

Average Alpha-

Particle Energy

\begin{tabular}{|c|c|c|c|c|c|}
\hline$(\mathrm{MeV})$ & Isotope & $\mathrm{Be}$ & $\mathrm{O}$ & $\mathrm{F}$ & $\mathrm{Al}$ \\
\hline 4.2 & ${ }^{238} \mathrm{U}$ & 26 & 0.019 & 1.4 & 0.04 \\
\hline 4.4 & ${ }^{235} \mathrm{U}$ & 31 & 0.025 & 2.0 & 0.07 \\
\hline 4.5 & ${ }^{236} \mathrm{U}$ & 35 & 0.028 & 2.2 & 0.09 \\
\hline 4.8 & ${ }^{233} \mathrm{U},{ }^{234} \mathrm{U}$ & 44 & 0.038 & 3.5 & 0.16 \\
\hline 5.3 & ${ }^{232} \mathrm{U}$ & 69 & 0.059 & 7.1 & 0.51 \\
\hline
\end{tabular}




\section{TABLE 19 - RATIOS OF WEIGHTS FOR PAIRS OF ISOTOPES AT WHICH THE NEUTRON YIELDS FOR EACH ISOTOPE OF THE PAIR ARE EQUAL}

\begin{tabular}{|c|c|c|c|c|}
\hline $\begin{array}{c}\text { Sample } \\
\text { Type }\end{array}$ & $\begin{array}{c}\text { Time Since } \\
\text { U Separation } \\
(\mathrm{yr}) \\
\end{array}$ & ${ }^{232} \mathrm{U} /{ }^{234} \mathrm{U}$ & ${ }^{232} \mathrm{U} /{ }^{235} \mathrm{U}$ & ${ }^{232} \mathrm{U} /{ }^{238} \mathrm{U}$ \\
\hline $\mathrm{UO}_{2}$ & $\begin{array}{r}0 \\
10\end{array}$ & $\begin{array}{l}1.8 \times 10^{-4} \\
1.7 \times 10^{-5}\end{array}$ & $\begin{array}{l}4.3 \times 10^{-8} \\
4.1 \times 10^{-9}\end{array}$ & $\begin{array}{l}8.2 \times 10^{-9} \\
7.8 \times 10^{-8}\end{array}$ \\
\hline $\mathrm{UF}_{6}$ & $\begin{array}{r}0 \\
10\end{array}$ & $\begin{array}{l}1.4 \times 10^{-4} \\
9.8 \times 10^{-6}\end{array}$ & $\begin{array}{l}2.8 \times 10^{-8} \\
1.9 \times 10^{-9}\end{array}$ & $\begin{array}{l}6.9 \times 10^{-9} \\
4.8 \times 10^{-10}\end{array}$ \\
\hline $\begin{array}{c}\mathrm{UAl}_{\mathrm{X}} \\
\left(\begin{array}{lll}20 \mathrm{wt} & \% & \mathrm{U}\end{array}\right)\end{array}$ & $\begin{array}{r}0 \\
10\end{array}$ & $\begin{array}{l}8.9 \times 10^{-5} \\
2.4 \times 10^{-6}\end{array}$ & $\begin{array}{l}1.4 \times 10^{-8} \\
3.7 \times 10^{-10}\end{array}$ & $\begin{array}{l}3.7 \times 10^{-8} \\
1.0 \times 10^{-9}\end{array}$ \\
\hline
\end{tabular}

Neutron multiplication is discussed in Section 4.1.1, and the general considerations presented there apply here also. Figures 17 and 18 are calculated multiplications for uranium and $\mathrm{UO}_{2}$ for solid cylinders where height equals diameter. Note the increases in multiplication with both enrichment and density. See Figure 6 for an example of the variation of multiplication with sample shape.

Active NDA techniques can be used to assay uranium. One such technique is to induce fissioning of uranium with neutrons whose energies are below the uranium $(n, f)$ threshold for even-numbered uranium isotopes. Cross sections for this reaction are shown in Figure 19. Note that for $<1 \mathrm{MeV}$ the neutron yield will be primarily from ${ }^{235} \mathrm{U}$. See Figure 8 for a neutron spectrum of a ${ }^{238} \mathrm{Pu}-\mathrm{Li}(\alpha, n)$ interrogation source. 


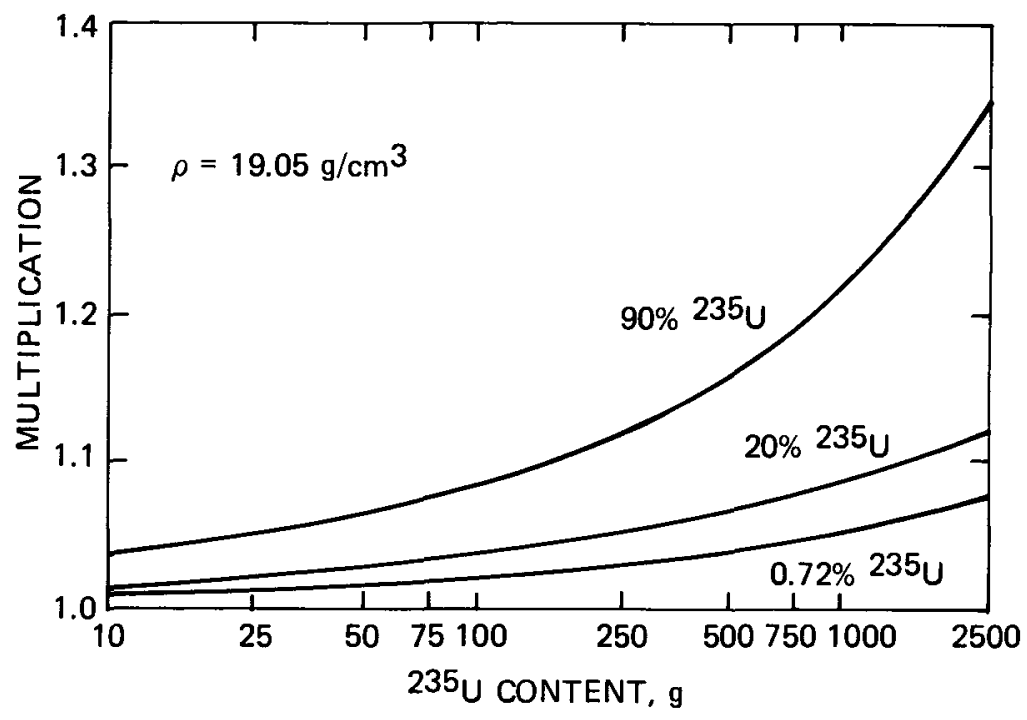

FIGURE 17 - Neutron self-multiplication for uranium metal in solid right cylinders where height equals diameter. ${ }^{3} \mathrm{U}$ enrichments are shown on the graph, the balance of the uranium is ${ }^{238} \mathrm{U}$.

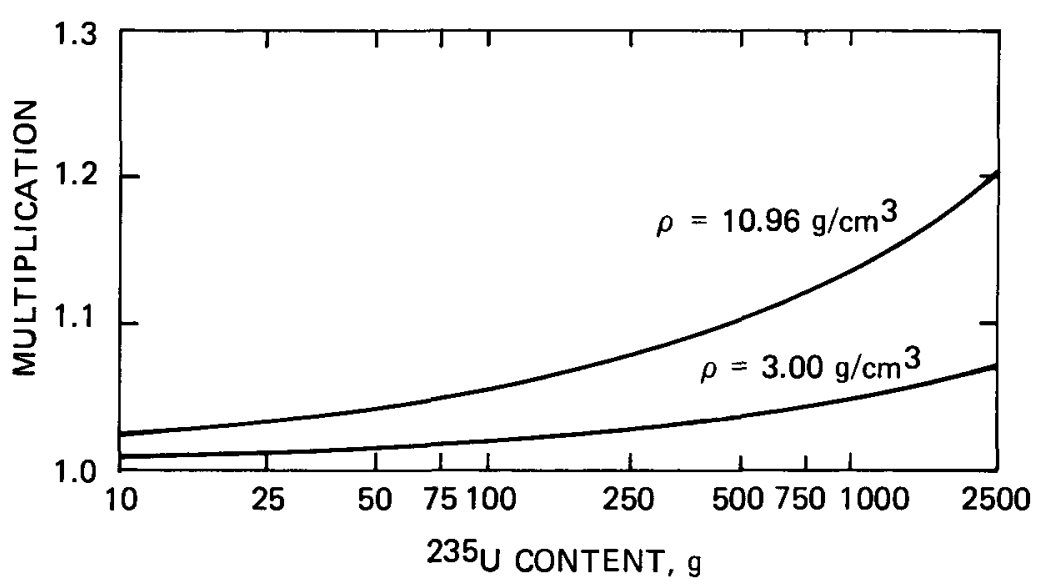

FIGURE 18 - Neutron self-multiplication for $\mathrm{UO}_{2}$ of two densities. Sample geometry is a solid right cylinder where height equals diameter. Uranium composition is: ${ }^{235} \mathrm{U}-90 \%$ and ${ }^{238} \mathrm{U}-10 \%$. 


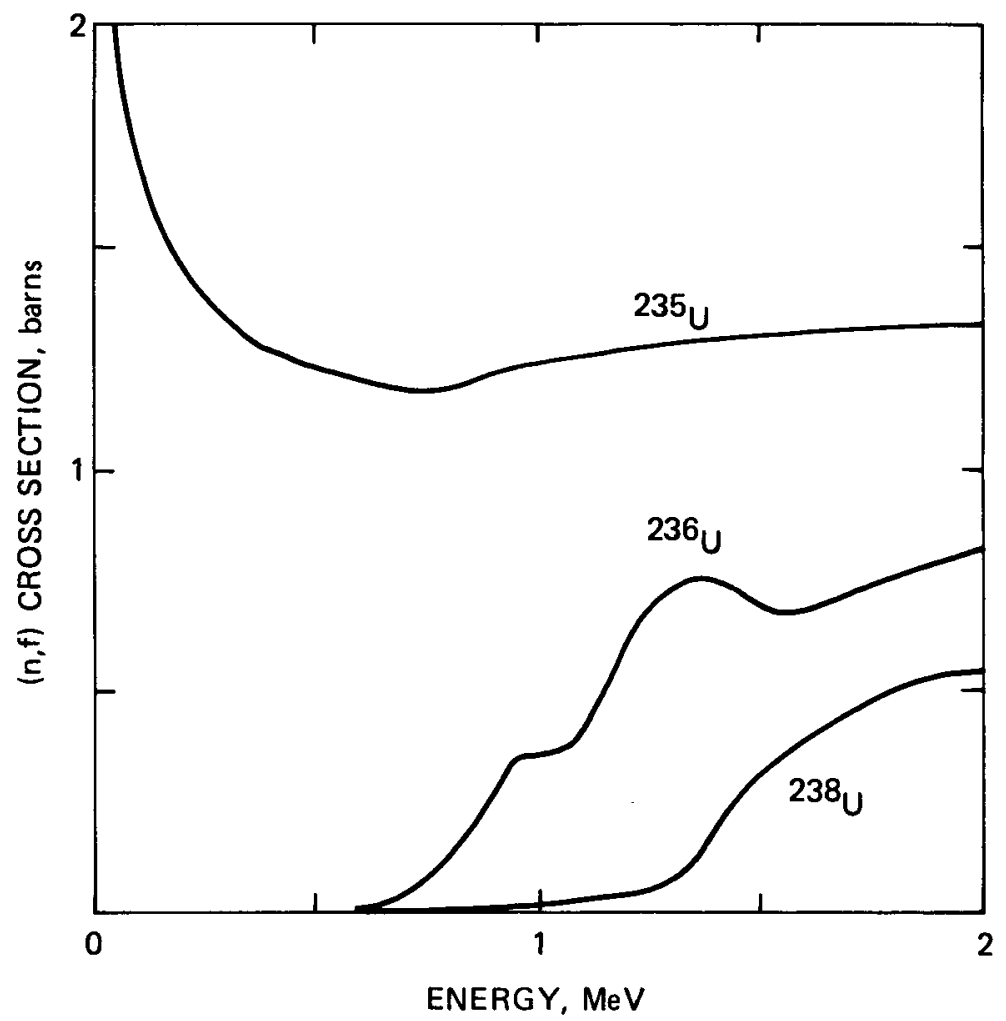

FIGURE 19 - Cross sections for uranium $(n, f)$ reactions. The uranium ( $\mathrm{n}, \mathrm{f}$ ) cross sections at $0.025 \mathrm{eV}$ (thermal neutrons) for ${ }^{235} \mathrm{U}$ and ${ }^{238} \mathrm{U}$ are 578 barns and $3 \times 10^{-6}$ barns, respectively. 


\subsubsection{Gamma-ray Properties}

Some of the more significant gamma rays for use in uranium NDA are listed in Table 20 . Uranium-236 was not included since its only gamma ray is one of low energy, $49.4 \mathrm{keV}$, and weak intensity. The gamma rays listed for ${ }^{238} \mathrm{U}$ actually come from the decay of ${ }^{234 \cdots} \mathrm{Pa}$, a granddaughter of ${ }^{238} \mathrm{U}$. Its ingrowth is governed by the 24.1 day halflife of its parent, ${ }^{234} \mathrm{Th}$. The ratio of the ${ }^{234 m} \mathrm{~Pa}$ activity following uranium separation to the activity at equilibrium can be given by:

$$
R=1-(1 / 2)^{n}
$$

where $\mathrm{n}$ is the number of ${ }^{234} \mathrm{Th}$ half-lives since separation. For example, after 96.4 days, $n=4$ and $R=0.9375$. Until such time as $R \sim 1$, the spectrum for $a^{238} \mathrm{U}$ sample will vary with time.

Figure 20 shows Nal spectra for thick $\left(\sim 4 \mathrm{~g}\right.$ of $\left.\mathrm{U} / \mathrm{cm}^{2}\right)$ samples of $\mathrm{U}_{3} \mathrm{O}_{8}$ for different enrichments; i.e., ${ }^{235} \mathrm{U} /$ total $\mathrm{U}$ ratios. For these spectra the ${ }^{234 m} \mathrm{~Pa}$ activity has reached equilibrium. The spectra are plotted for a constant ${ }^{238} \mathrm{U}$ content. Since the portion of each spectrum $>270 \mathrm{keV}$ is essentially due only to ${ }^{238} \mathrm{U}$, the single curve shown in this energy region is common to all spectra. Each point in the background spectrum is $\leqslant 10 \%$ of the natural uranium spectrum.

Figure 21 shows Ge spectra for the same samples used for the $\mathrm{Nal}$ spectra and plotted in the same manner. For clarity, only the natural uranium and $90 \%$ enrichment spectra are shown. Again, the portion for energies $>270 \mathrm{keV}$ is essentially common to both spectra. Peaks in the background for this unshielded measurement have been marked.

The general considerations for gamma-ray absorption by sample and container and for enrichment measurements discussed in Section 3.1.2 apply here, also.

Figure 22 is a plot of uranium attenuation coefficients and is only slightly different from the corresponding plot for plutonium. The $\mathrm{K}$-absorption edge for uranium is at $115.6 \mathrm{keV}$ (for plutonium it is $121.8 \mathrm{keV}$ ). The $185.7 \mathrm{keV}$ gamma ray for ${ }^{235} \mathrm{U}$ is commonly used for assay purposes. However, the uranium attenuation coefficient at this energy is sufficiently large that most of the gamma rays emitted originate in the outer layers of the sample. Effective mass attenuation coefficients are given in Table 21 . 
TABLE 20 - PRINCIPAL GAMMA RAYS FROM URANIUM

\begin{tabular}{|c|c|c|}
\hline Isotope & $\begin{array}{c}\text { Energy } \\
(\mathrm{keV})\end{array}$ & $\begin{array}{c}\text { Intensity } \\
(\gamma / \mathrm{sec}-\mathrm{g} \text { of isotope })\end{array}$ \\
\hline${ }^{232} \mathrm{U}$ & $\begin{array}{l}129.1 \\
270.5 \\
327.8\end{array}$ & $\begin{array}{l}6.5 \times 10^{8} \\
3.0 \times 10^{7} \\
2.7 \times 10^{7}\end{array}$ \\
\hline${ }^{233} \mathrm{U}$ & $\begin{array}{l}119.0 \\
120.8 \\
146.4 \\
164.6 \\
245.3 \\
291.3 \\
317.2\end{array}$ & $\begin{array}{l}3.9 \times 10^{4} \\
3.2 \times 10^{4} \\
6.6 \times 10^{4} \\
6.4 \times 10^{4} \\
3.8 \times 10^{4} \\
5.8 \times 10^{4} \\
8.3 \times 10^{4}\end{array}$ \\
\hline${ }^{234} \mathrm{U}$ & 120.9 & $5.4 \times 10^{5}$ \\
\hline${ }^{235} \mathrm{U}$ & $\begin{array}{l}143.8 \\
163.4 \\
185.7 \\
202.1 \\
205.3\end{array}$ & $\begin{array}{l}7.8 \times 10^{3} \\
3.7 \times 10^{3} \\
4.3 \times 10^{4} \\
8.0 \times 10^{2} \\
4.0 \times 10^{3}\end{array}$ \\
\hline $\begin{array}{l}{ }^{238} \mathrm{U} \text { in equilibrium } \\
\text { with }{ }^{234 m} \mathrm{~Pa}\end{array}$ & $\begin{array}{r}742.8 \\
766.4 \\
786.3 \\
1001.0\end{array}$ & $\begin{array}{l}7.1 \\
2.6 \times 10^{1} \\
4.3 \\
7.5 \times 10^{1}\end{array}$ \\
\hline
\end{tabular}




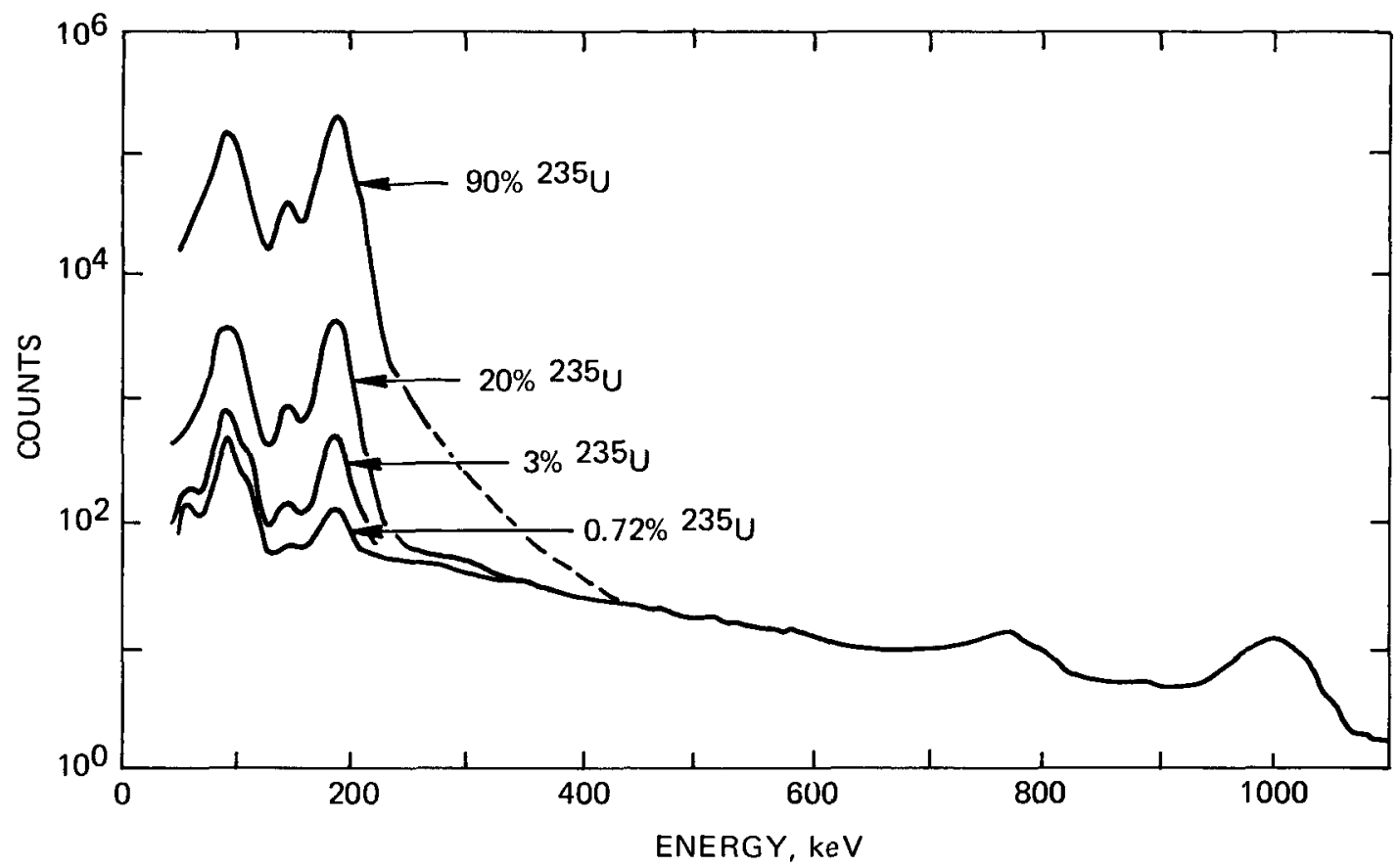

FIGURE 20 - Gamma-ray spectra of natural uranium $\left(0.72 \%{ }^{235} \mathrm{U}\right)$ and of $3 \%, 20 \%$, and $90 \%{ }^{23 .} \mathrm{U} / \mathrm{U}$ enrichments obtained with a shielded 3 in. $x 3$ in. NaI detector. 


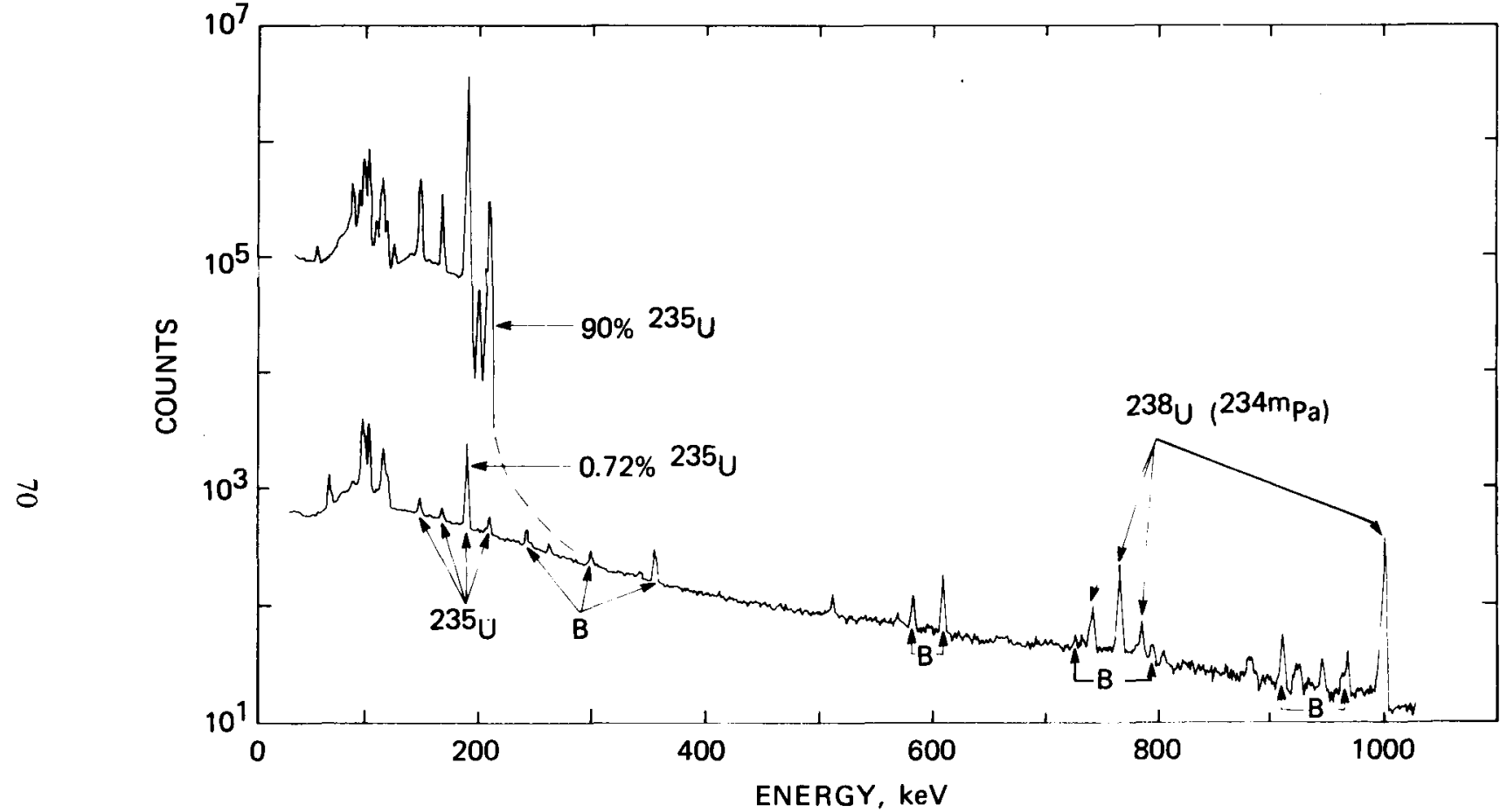

FIGURE 21 - Gamma-ray spectra of natural uranium $\left(0.72 \%{ }^{235} \mathrm{U}\right)$ and $90 \%{ }^{235} \mathrm{U}$ enrichment, obtained with an unshielded $14 \% \mathrm{GeLi}$ detector. Peaks marked ${ }^{235} \mathrm{U}$ are primarily from this isotope and those marked ${ }^{238} \mathrm{U}\left({ }^{2341} \mathrm{~Pa}\right)$ are from the decay of ${ }^{234 n} \mathrm{~Pa}$. Peaks in the background are marked $\mathrm{B}$. 


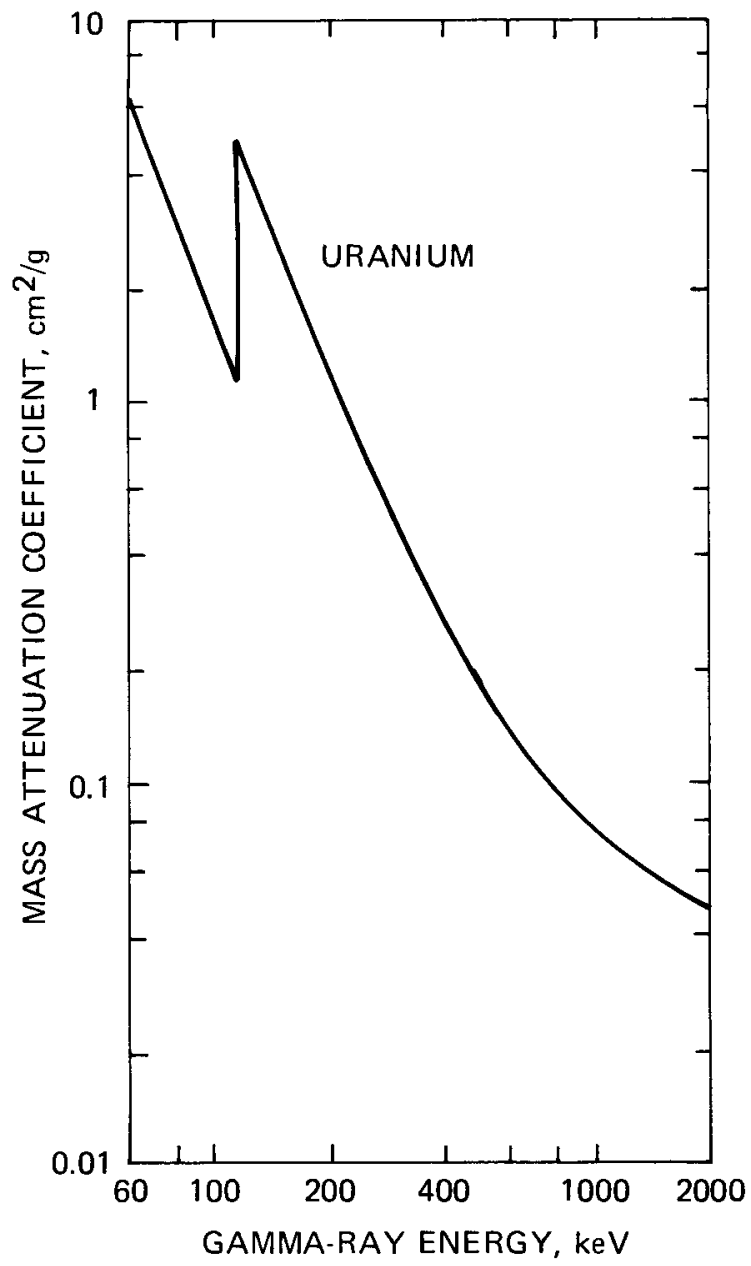

FIGURE 22 - Mass attenuation coefficients for uranium. 
TABLE 21 - EFFECTIVE MASS ATTENUATION COEFFICIENTS AT $186 \mathrm{keV}$ FOR SELECTED MATERIALS

\begin{tabular}{cc} 
Material & $\mu\left(\mathrm{cm}^{2} / \mathrm{g}\right)$ \\
\cline { 2 - 2 } $\mathrm{U}$ & 1.46 \\
$\mathrm{UO}_{2}$ & 1.30 \\
$\mathrm{U}_{3} \mathrm{O}_{8}$ & 1.26 \\
$\mathrm{UF}_{6}$ & 1.02 \\
$\mathrm{UAl}_{\mathrm{X}}(20 \mathrm{wt} \% \mathrm{U})$ & 0.39 \\
$\mathrm{Fe}$ & 0.14 \\
$\mathrm{Al}$ & 0.12
\end{tabular}




\subsubsection{Thermal Properties}

Thermal power produced by uranium samples is primarily a result of $\alpha$-decay. Table 22 is a list of specific powers for uranium isotopes. Because uranium isotopes in common use have longer half-lives than comparable plutonium isotopes, the specific powers are lower. For example, the specific power for ${ }^{23} \mathrm{U}$ is only $0.0031 \%$ of that for ${ }^{239} \mathrm{Pu}$.

Equation 7 can be used to calculate the total specific power for a sample. Unless a sample contains a significant amount of ${ }^{232} \mathrm{U}$, the specific power will be essentially constant over several years.

TABLE 22 - SPECIFIC POWERS FOR URANIUM ISOTOPES

$\begin{array}{lcccc}\text { Isotope } & \begin{array}{c}\text { Specific Power } \\ \text { (mW/g of isotope) }\end{array} & & \text { Isotope } & \begin{array}{c}\text { Specific Power } \\ \text { (mW/g of isotope) }\end{array} \\ { }^{232} \mathrm{U} & 7.0 \times 10^{2} & & { }^{235} \mathrm{U} & 5.72 \times 10^{-5} \\ { }^{233} \mathrm{U} & 2.78 \times 10^{-1} & & { }^{236} \mathrm{U} & 1.74 \times 10^{-3} \\ { }^{234} \mathrm{U} & 1.78 \times 10^{-1} & & { }^{238} \mathrm{U} & 8.45 \times 10^{-6}\end{array}$





\section{Appendix}

References for data used in this Handbook are given in this appendix.

References for total half-lives in Tables 3 and 16 are shown in Table A. References for spontaneous fission half-lives and neutron yield per spontaneous fission $\left(\bar{v}_{S F}\right)$, which were used to calculate the spontaneous fission yield in Tables 4 and 17, are also shown in Table A. Specific powers for plutonium isotopes are from Reference 5 . Other specific powers were calculated. Thick target $(\alpha, n)$ yields for all elements except beryllium came from Reference 13 . The beryllium thick target yields came from Reference 14 .

Stopping powers are from References 15 and 16 with the latter used for lithium, boron, and fluorine. In connection with stopping powers it should be pointed out that Equation 1 on page 30 is an approximation of the more complete expression involving integration over the range of alpha-particle energies involved.

BNL 325 (Reference 17) was used for all neutron cross sections.

The ${ }^{238} \mathrm{Pu}-\mathrm{Li}(\alpha, \mathrm{n})$ neutron spectrum is a smooth curve through the data given in Reference 18.

References for average energies for neutron energy spectra given in Table 8 are: ${ }^{240} \mathrm{Pu}$ (spontaneous fission), $19 ;{ }^{252} \mathrm{Cf}$ (spontaneous fission), 20; ${ }^{238} \mathrm{Pu}-\mathrm{Li}(\alpha, \mathrm{n}), \quad 18 ;{ }^{239} \mathrm{Pu}-\mathrm{F}(\alpha, \mathrm{n}), 21 ;{ }^{238} \mathrm{Pu}-\mathrm{O}(\alpha, \mathrm{n}), \quad 22$; ${ }^{239} \mathrm{Pu}-\mathrm{Be}(\alpha, \mathrm{n}), 23$.

The gamma-ray branching ratios used to calculate gamma-ray yields for Tables 9 and 20 came from Reference 24 .

Reference 25 was the source for photon cross sections used in all gamma-ray attenuation calculations. 
Table A - REFERENCES FOR HALF-LIVES AND $\bar{\nu}_{S F}$ IN THIS HANDBOOK

\begin{tabular}{|c|c|c|c|}
\hline Isotope & $\begin{array}{c}\text { Total } \\
\text { Half-Life }\end{array}$ & $\begin{array}{c}\text { Spontaneous } \\
\text { Fission } \\
\text { Half-Life }\end{array}$ & $\bar{\nu}_{S F}$ \\
\hline${ }^{232} \mathrm{U}$ & 3 & 4 & 12 \\
\hline${ }^{23} \mathrm{U}$ & 3 & 6 & $12^{b}$ \\
\hline${ }^{234} \mathrm{U}$ & 3 & 6 & $-\mathrm{c}$ \\
\hline${ }^{235} \mathrm{U}$ & 3 & 6 & $12^{b}$ \\
\hline${ }^{236} \mathrm{U}$ & 3 & 6 & 12 \\
\hline${ }^{23}{ }^{2} \mathrm{U}$ & 4 & - & - \\
\hline${ }^{238} \mathrm{U}$ & 3 & 3 & 12 \\
\hline${ }^{238} \mathrm{Pu}$ & 4 & $7,8^{\mathrm{a}}$ & 12 \\
\hline${ }^{239} \mathrm{Pu}$ & 4 & 4 & $12^{b}$ \\
\hline${ }^{240} \mathrm{Pu}$ & 5 & 9 & 12 \\
\hline${ }^{24 !} \mathrm{Pu}$ & 5 & 10 & $12^{\mathrm{b}}$ \\
\hline${ }^{242} \mathrm{Pu}$ & 4 & 4 & 12 \\
\hline${ }^{241} \mathrm{Am}$ & 5 & 4 & $12^{b}$ \\
\hline${ }^{242} \mathrm{Cm}$ & 4 & 11 & 12 \\
\hline${ }^{244} \mathrm{Cm}$ & 4 & 4 & 12 \\
\hline${ }^{252} \mathrm{Cf}$ & - & 4 & 12 \\
\hline
\end{tabular}

a The value used is the mean of the values from these two references.

b Equation 2 on page 655 of Reference 12 was used to calculate an approximate value for $\bar{\nu}_{S F}$.

c $\bar{\nu}_{S F}$ for ${ }^{234} \mathrm{U}$ is estimated to be 1.9 . 


\section{References}

1. J. E. Cline, E. B. Nieschmidt, A. L. Connelly and E. L. Murri, "A Technique for Assay of L-10 Bottles of Plutonium Nitrate," IN-1433, Idaho Nuclear Corporation (1970).

2. T. W. Crane, "Test and Evaluation Results of the ${ }^{252} \mathrm{Cf}$ Shuffler at the Savannah River Plant," LA-8755-MS, Los Alamos National Laboratory (1981).

3. N. E. Holden, "The Uranium Half-Lives: A Critical Review," BNL-NCS-51320, Brookhaven National Laboratory (1981).

4. "Proposed Recommended List of Transactinium Isotope Decay Data, Part I. Half-Lives," INDC(NDS)-108/N, IAEA (1979).

5. "Calibration Techniques for the Calorimetric Assay of Plutonium-Bearing Solids Applied to Nuclear Materials Control," ANSI N15.22, American National Standards Institute (1975).

6. H. R. von Gunten, A. Grütter, H. W. Reist, and M. Baggenstos, "Ground-State Spontaneous-Fission Half-Lives of Uranium Isotopes," Phys. Rev., C23 (1981) 23.

7. J. D. Hastings and W. W. Strohm, "The Spontaneous Fission Half-Life of ${ }^{238} \mathrm{Pu}, "$ J. Inorg. Nucl. Chem., 34 (1971) 25.

8. R. Gay and R. Sher, "Spontaneous Fission Decay Constant of Plutonium-238," Proceedings of the Conference on Nuclear Cross Sections and Technology, NBS SP 425 (1975) 587.

9. "INDC/NEANDC Nuclear Standards File 1980 Version," IAEA Report INDC-36/LN.

10. D. L. Johnson, "Evaluation of Neutron Yields from Spontaneous Fission of Transuranic Isotopes, Trans. Am. Nucl. Soc., 22 (1975) 673. 
11. R. J. Armani and R. Gold, "Spontaneous Fission Half-Lives of ${ }^{242} \mathrm{Cm}$ and ${ }^{244} \mathrm{Cm}$ by Absolute Alpha and Neutron Counting," IAEA Symposium on the Standardization of Radionuclides, Vienna, 1966, CONF-661012-30 Preprint No. SM-79-53.

12. F. Manero and V. A. Konshin, "Status of the Energy-dependent $v$-Values for the Heavy Isotopes $\mathrm{Z}>90$ from Thermal to $15 \mathrm{MeV}$ and of $\nu$-Values for Spontaneous Fission," At. Energy Rev., 10 (1972) 637.

13. J. K. Bair and J. Gomez del Campo, "Neutron Yields from Alpha-Particle Bombardment," Nucl. Sci. Eng., 71 (1979)18.

14. M. E. Anderson and M. R. Hertz, "Thick Target Yields for the ${ }^{9} \operatorname{Be}(\alpha, n)$ Reaction," Nucl. Sci. Eng., 44 (1971) 437.

15. L. C. Northcliffe and R. F. Schilling, "Range and StoppingPower Tables for Heavy Ions," Nucl. Data Tables, A7 (1970) 233.

16. J. F. Ziegler and W. K. Chu, "Stopping Cross Sections and Backscattering Factors for ${ }^{4} \mathrm{He}$ Ions in Matter, $\mathrm{Z}=1-92, \mathrm{E}\left({ }^{4} \mathrm{He}\right)$ $=400-4000 \mathrm{keV}$," At. Data and Nucl. Data Tables, 13 (1974) 463.

17. "Neutron Cross Sections," BNL 325, Brookhaven National Laboratory (1964).

18. H. Ing, W. B. Cross, and B. J. Tymons, "The Spectrum of Neutrons from a ${ }^{238} \mathrm{Pu}-\mathrm{Li}$ Source," Health Phys., 40 (1981) 345.

19. T. W. Bonner, "Measurements of Neutron Spectra from Fission," Nucl. Phys., 23 (1961) 116.

20. J. A. Grundl and C. M. Eisenhauer, "Fission Spectrum Neutrons for Cross Section Validation and Neutron Flux Transfer," Proceedings of the Conference on Nuclear Cross Sections and Technology, NBS SP 425 (1975) 250.

21. O. P. Massand and G. Venkataraman, "The Neutron Spectrum of Plutonium Fluoride," Nucl. Inst. Meth., 121 (1974) 405.

22. M. E. Anderson, "Neutron Energy Spectra of a ${ }^{238} \mathrm{Pu}-{ }^{18} \mathrm{O}(\alpha, \mathrm{n})$ Source-Unmoderated and Polyethylene Moderated," Health Phys., 39 (1980) 537. 
23. M. E. Anderson and R. A. Neff, "Neutron Energy Spectra of Different Size ${ }^{239} \mathrm{Pu}-\mathrm{Be}(\alpha, \mathrm{n})$ Sources," Nucl. Inst. Meth., 99 (1972) 231.

24. R. Gunnink, J. E. Evans, and A. L. Prindle, "A Reevaluation of the Gamma-Ray Energies and Absolute Branching Intensities of ${ }^{237} \mathrm{U},{ }^{238},{ }^{239},{ }^{240},{ }^{241} \mathrm{Pu}$ and ${ }^{241} \mathrm{Am}, " \mathrm{UCRL}-52139$, Lawrence Livermore National Laboratory (1976).

25. E. Storm and H. I. Israel, "Photon Cross Sections from $1 \mathrm{keV}$ to $100 \mathrm{MeV}$ for Elements $Z=1$ to $Z=100$," Nucl. Data Tables A7 (1970) 565. 